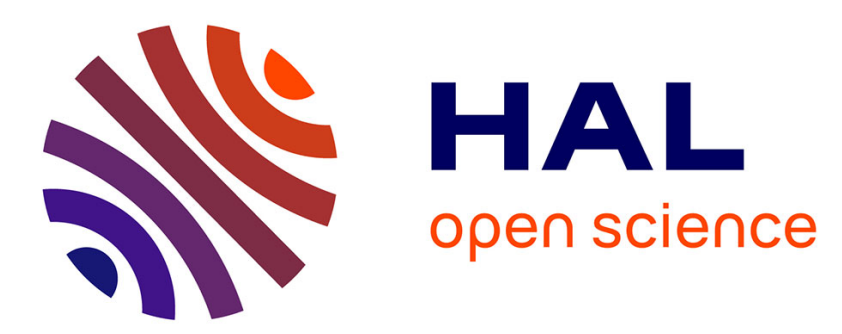

\title{
A low temperature chlorination-volatilization process for the treatment of chalcopyrite concentrates
}

Ndue Kanari, I. Gaballah, Eric Allain

\section{To cite this version:}

Ndue Kanari, I. Gaballah, Eric Allain. A low temperature chlorination-volatilization process for the treatment of chalcopyrite concentrates. Thermochimica Acta, 2001, 373 (1), pp.75-93. 10.1016/S00406031(01)00454-3 . hal-01510097

\section{HAL Id: hal-01510097 \\ https://hal.univ-lorraine.fr/hal-01510097}

Submitted on 23 May 2017

HAL is a multi-disciplinary open access archive for the deposit and dissemination of scientific research documents, whether they are published or not. The documents may come from teaching and research institutions in France or abroad, or from public or private research centers.
L'archive ouverte pluridisciplinaire HAL, est destinée au dépôt et à la diffusion de documents scientifiques de niveau recherche, publiés ou non, émanant des établissements d'enseignement et de recherche français ou étrangers, des laboratoires publics ou privés. 


\title{
First Version
}

\section{A Low Temperature Chlorination-Volatilization Process for the Treatment of Chalcopyrite Concentrates}

\author{
N. KANARI, I. GABALLAH, and E. ALLAIN* \\ Mineral Processing and Environmental Engineering team, \\ LEM $^{\mathrm{a}}, \mathrm{CNRS}^{\mathrm{b}} \mathrm{UMR}^{7569}, \mathrm{ENSG}^{\mathrm{c}}, \mathrm{INPL}^{\mathrm{d}}$, BP 40, 54501 Vandœuvre, France \\ * University of Missouri-Rolla, School of Mines and Metallurgy, Center for Pyrometallurgy \\ 210 Fulton Hall, 65401 Rolla, MO, USA
}

The chlorination of two chalcopyrite concentrates with $\mathrm{Cl}_{2}+\mathrm{N}_{2}$ was investigated under isothermal conditions in the temperatures range from $20^{\circ} \mathrm{C}$ to $750{ }^{\circ} \mathrm{C}$ using boat experiments. The effects of gas flow rate, chlorine content of the gas mixture and reaction time on the reaction rate were also investigated. The reaction products were analyzed by SEM, XRD, and chemical analysis.

The chlorination of chalcopyrite concentrates started from room temperature generating chlorides of $\mathrm{Cu}, \mathrm{Pb}, \mathrm{Zn}, \mathrm{Fe}$, and $\mathrm{S}$. The reaction of chlorine with sulfides is almost complete at about $300{ }^{\circ} \mathrm{C}$ and the overall reaction is exothermic. At this temperature, the more valuable metals' chlorides were concentrated in the chlorination residues, while those of iron and sulfur were volatilized. Chlorination at higher temperatures allowed the volatilization of valuable metal chlorides. A process for the selective chlorination of chalcopyrite concentrates at low temperatures was suggested. It could be considered as an attractive route for the sulfides' treatment without $\mathrm{SO}_{\mathrm{x}}$ emissions. In addition, low operating temperatures offer another advantage for the chlorination process with regard to higher energy consumption of the common pyrometallurgical routs.

\footnotetext{
a. Laboratoire Environnement et Minéralurgie, rue du Doyen M. Roubault, BP 40, 54501 Vandœuvre Cedex, France.

b. Centre National de la Recherche Scientifique, 3 rue MichelAnge, 75794 Paris Cedex, France.

c. École Nationale Supérieure de Géologie, rue du Doyen M. Roubault, BP 40, 54501 Vandœuvre Cedex, France.

d. Institut National Polytechnique de Lorraine, 2 rue de la Forêt de Haye, 54501 Vandœuvre Cedex, France.
} 


\section{INTRODUCTION}

In a previous paper from this laboratory[1], the kinetics of the chlorination of the chalcopyrite concentrates at temperature up to $300{ }^{\circ} \mathrm{C}$, using thermogravimetric analysis (TGA), were discussed in details. It was observed that the chlorination of chalcopyrite concentrates was generally little dependent on the temperature and the reaction times of few minutes were sufficient at $300{ }^{\circ} \mathrm{C}$ to achieve full chlorination of sulfides and volatilization of the sulfur and iron chlorinated-compounds. However, the kinetics study was performed with several milligrams of samples in order to minimize the effect of mass and heat transfer phenomena on the chlorination process.

Even using TGA experiments, the chlorination rate as well as the volatilization rate of the chlorides is affected by the amount of sample used. Figures 1 (a) to (c) gather some data concerning the chlorination of a chalcopyrite concentrate at $300{ }^{\circ} \mathrm{C}$ using 12,25 , and $50 \mathrm{mg}$ of sample for various chlorine contents in the gas mixture. About 60 minutes were necessary to achieve full chlorination of sulfides and volatilization of $\mathrm{S}_{\mathrm{x}} \mathrm{Cl}_{\mathrm{y}}$ and $\mathrm{FeCl}_{3}$ when $50 \mathrm{mg}$ of sample were chlorinated by a $\mathrm{Cl}_{2}+\mathrm{N}_{2}$ gas mixture containing $10 \% \mathrm{Cl}_{2}$. The reaction time became about 6 times shorter when the amount of the sample used was $12 \mathrm{mg}$. As it could be expected, the reaction time decreased with the increase of the chlorine content in the chlorinating gas mixture. Thus, about 3 minutes are sufficient to reach a complete reaction of the sample by chlorine alone when $12 \mathrm{mg}$ of the sample were used (refer to Figure 1 (c)). Results obtained suggested that the fluidized bed will be the best reactor from the chlorination kinetics point of view. Nevertheless, the partial fusion as well as the softening of materials occurred during the chlorination of sulfides resulting in the choking of the fluidized bed.

The literature review, summarized in Reference 1, revealed that low $\left(\leq 300{ }^{\circ} \mathrm{C}\right)$ and high $\left(\geq 400{ }^{\circ} \mathrm{C}\right.$ ) temperatures were used for the chlorination of sulfides. However, the use of temperatures higher or equal to $500{ }^{\circ} \mathrm{C}$ will lead to the partial decomposition of chalcopyrite and pyrite to cubanite and pyrrhotite, respectively[2], this prior to the chlorination gas mixture will be introduced. On the other hand, the use of high chlorination temperatures will cause the partial volatilization of valuable metal chlorides such as $\mathrm{CuCl}_{2}, \mathrm{CuCl}, \mathrm{ZnCl}_{2}, \mathrm{PbCl}_{2}$, besides $\mathrm{S}^{\circ}, \mathrm{FeCl}_{3}$, and $\mathrm{S}_{\mathrm{X}} \mathrm{Cl}_{\mathrm{y}}$, decreasing the selectivity of the chlorination process.

For these reasons, the chlorination of several grams of the chalcopyrite concentrates was carried out from room temperature to $750{ }^{\circ} \mathrm{C}$ using boat experiments. The results are discussed in terms of the effects of gas flow rate, temperature, chlorine content, and reaction time on the chlorination rate of the chalcopyrite concentrates as well as on the selective volatilization and separation of valuable metals' chlorides from those of iron and sulfur. 


\section{MATERIALS AND EXPERIMENTAL PROCEDURES}

\section{A. Materials}

Two chalcopyrite concentrates as well as $\mathrm{CuFeS}_{2}, \mathrm{ZnS}, \mathrm{PbS}$, and $\mathrm{FeS}_{2}$ were the selected materials used for this investigation. Their physico-chemical characteristics were described in details previously[1]. The chemical and mineralogical compositions of two concentrates are given in Table I. As shown, these concentrates are characterized by different contents of valuable metals $(\mathrm{Cu}, \mathrm{Pb}$, and $\mathrm{Zn})$. The valuable metal $(\mathrm{Cu}, \mathrm{Zn})$ content of first sample was about 11.6 pct and was called low grade concentrate (LGC). The total valuable metal $(\mathrm{Cu}, \mathrm{Zn}, \mathrm{Pb})$ content of second sample was about 36.5 pct and it was designated as high grade concentrate (HGC). The major sulfides of the LGC were $\mathrm{CuFeS}_{2}$ and $\mathrm{FeS}_{2}$. The LGC gangue essentially contained quartz and clinochlore. The HGC was rich in chalcopyrite (81.7 pct). Moreover, it bore some amounts of lead and zinc compounds, whilst its gangue content was low.

Table I. Chemical and Mineralogical Composition of the Chalcopyrite Concentrates (Wt pct).

\begin{tabular}{|c|c|c|c|c|c|}
\hline Element & LGC & HGC & Phases & LGC & HGC \\
\hline $\mathrm{Cu}$ & 10.8 & 28.3 & $\mathrm{CuFeS}_{2}$ & 31.2 & 81.7 \\
\hline $\mathrm{Fe}$ & 29.7 & 26.3 & $\mathrm{FeS}_{2}$ & 23.8 & 3.0 \\
\hline$S$ & 24.0 & 32.1 & $\mathrm{ZnS}$ & 1.2 & 6.4 \\
\hline $\mathrm{Zn}$ & 0.8 & 4.3 & $\mathrm{CaCO}_{3}$ & 3.2 & - \\
\hline $\mathrm{Pb}$ & - & 3.9 & $\mathrm{PbSO}_{4}$ & - & 5.7 \\
\hline $\mathrm{Ca}$ & 1.3 & - & $\mathrm{MgO}$ & 1.9 & - \\
\hline $\mathrm{Si}$ & 6.7 & 0.3 & $\mathrm{SiO}_{2}$ & 14.4 & 0.7 \\
\hline $\mathrm{Al}$ & 2.1 & - & $\mathrm{FeO}$ & 11.8 & - \\
\hline $\mathrm{Mg}$ & 1.2 & - & $\mathrm{Al}_{2} \mathrm{O}_{3}$ & 4.0 & - \\
\hline $\mathrm{O}$ & 14.5 & 1.6 & Clinochlore ${ }^{*}$ & ND & - \\
\hline Total & 91.1 & 96.8 & & 91.5 & 97.5 \\
\hline
\end{tabular}

Clinochlore : $(\mathrm{Mg}, \mathrm{Fe})_{6}(\mathrm{Si}, \mathrm{Al})_{4} \mathrm{O}_{10}(\mathrm{OH})_{8}$.

\section{B. Experimental Procedures}

Test of the isothermal chlorination of chalcopyrite concentrates was carried out using the experimental set-up schematized in Figure 2. This apparatus is composed of a gas-metering unit followed by a gas-purification system and a horizontal furnace. Several grams of sample were spread uniformly in a quartz boat (10 cm long, $1 \mathrm{~cm}$ wide, and $1.5 \mathrm{~cm}$ deep). The boat of sample is placed into the reactor, and heating at the desired temperature was done under nitrogen atmosphere. Since then, the nitrogen flow was turned off and the chosen chlorinating gas mixture was 
introduced in the reactor. The solid condensates were recovered after their condensation on the reactor wall because of the natural temperature gradient. The composition of the chlorination products was determined by scanning electron microscopy (SEM), X-ray diffraction (XRD), and inductively coupled plasma-atomic emission spectrometry (ICP-AES). Few experiments were also performed by using the TGA set-up described earlier[3], this in order to record continuously the evolution of the sample weight.

As the boat used for the experimental tests was relatively long, attempts were made to measure the temperature distribution of the whole sample. Thus, the temperature of the furnace was fixed at a desired value, between $200{ }^{\circ} \mathrm{C}$ and $600{ }^{\circ} \mathrm{C}$, and the temperature at the sample surface was recorded by setting a thermocouple inside of the reactor. Similarly, the inner temperatures of the entire reactor and condenser were measured. The tests were carried out under nitrogen atmosphere. Figure 3 represents the results obtained. It is obvious that the temperature at the whole sample was almost constant $\left( \pm 5^{\circ} \mathrm{C}\right)$ on the temperature interval checked. This figure shows also the temperature profile of the condensation zone of chlorides and the location where from the condensates (named as $\mathrm{C}_{1}$ and $\mathrm{C}_{2}$ ) were dragged away to be analyzed.

The sample temperature was also measured during the chlorination at $300{ }^{\circ} \mathrm{C}$ of both chalcopyrite concentrates (LGC and HGC) by $\mathrm{Cl}_{2}+\mathrm{N}_{2}$ at various contents of chlorine in the gas mixture, this in order to determine the increase of temperature due to the exothermic nature of the chlorination reactions of the sulfides. The results will be reported in Section III of this article.

\section{RESULTS AND DISCUSSION}

\section{A. Effect of the Gas Flow Rate}

Experimental tests to check the effect of the gas flow rate on the chlorination of two chalcopyrite concentrates were performed at $300{ }^{\circ} \mathrm{C}$ by using the $\mathrm{Cl}_{2}+\mathrm{N}_{2}$ gas mixture with a $\mathrm{Cl}_{2} / \mathrm{N}_{2}$ molar ratio equal to 1 . The reaction time was fixed to be $1 \mathrm{~h}$. Figure 4 traces the percentage weight loss (PWL) of the used samples as a function of the gas flow rate. The chlorination of the HGC seems to be more affected than the LGC one by the gas flow rate. However, a flow rate higher than to $20 \mathrm{~L} / \mathrm{h}$ (gas velocity: ' $\mathrm{V}_{\mathrm{g}} \approx 0.42 \mathrm{~cm} / \mathrm{s}$ ) will be adequate for the minimization of mass transfer

phenomena. Since, a chlorinating gas mixture with a $\mathrm{V}_{\mathrm{g}} \approx 0.84 \mathrm{~cm} / \mathrm{s}$ was used for the study of the chlorination of both concentrates at different temperatures.

\section{B. Chlorination of Sulfides at Different Temperatures for 2 Hours}

An extensive series of the isothermal chlorination tests was carried out between $20{ }^{\circ} \mathrm{C}$ and $750{ }^{\circ} \mathrm{C}$. The materials subjected to chlorination were LGC, $\mathrm{HGC}, \mathrm{CuFeS}_{2}, \mathrm{FeS}_{2}, \mathrm{ZnS}$, and PbS. A 
chlorinating gas mixture of $\mathrm{Cl}_{2}+\mathrm{N}_{2}\left(\mathrm{Cl}_{2} / \mathrm{N}_{2}=1\right)$ was used and the reaction time was 2 hours. Results are represented in Figure 5 as evolution of PWL versus temperature. Pyrite and chalcopyrite started to react from room temperature and a maximum weight gain was observed at $200{ }^{\circ} \mathrm{C}$. Full reaction and volatilization of the reaction products for the pyrite chlorination were achieved at 300 ${ }^{\circ} \mathrm{C}$. A plateau of weight loss was observed at about $350{ }^{\circ} \mathrm{C}$ for the chalcopyrite chlorination, since then the PWL increased continuously with temperature. The sulfides of zinc and lead reacted with chlorine at temperatures equal to or higher than $150{ }^{\circ} \mathrm{C}$ leading to their respective chlorides. However, complete reaction of $\mathrm{ZnS}$ was achieved at temperature lower than that of PbS. These observations for the chlorination of the sulfides suggest that full reaction and volatilization of products depend on the vapor pressure the chlorides. As shown in Figure 6[4], the chlorides of sulfur, iron, copper, zinc, and lead are characterized by a wide difference on the vapor pressure at a given temperature and the sequence of the sulfides' chlorination follows that of the chlorides' volatilization. Cupric chloride was expected to be decomposed into cuprous chloride followed by the volatilization of the last.

The behavior of HGC chlorination is close to that of chalcopyrite, whilst that of LGC is similar in sequence to : pyrite in $\mathrm{Cl}_{2}+\mathrm{N}_{2}$ up to $275{ }^{\circ} \mathrm{C}$, and chalcopyrite in $\mathrm{Cl}_{2}+\mathrm{N}_{2}$ for higher temperatures. These similarities are consistent with the chemical composition of these concentrates (refer to Table I). Figure 5 contains the calculated limits (expressed as PWL) for the selective chlorination of each concentrates and they were designed as $\mathrm{L}_{1}$ and $\mathrm{L}_{2}$ for LGC and HGC, respectively. They were defined assuming a full chlorination of sulfides and volatilization of iron and sulfur compounds. The validity of these limits will be discussed after the qualitative and quantitative analyses of the reaction products of the chlorination of both concentrates. However, these limits seem to be close to the experimental PWL obtained for the two concentrates at $300{ }^{\circ} \mathrm{C}$.
$4 \mathrm{CuFeS}_{2}$

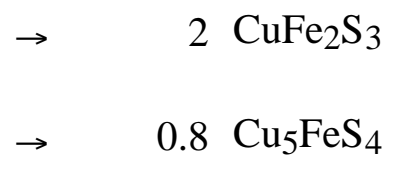
$\mathrm{Cu}_{2} \mathrm{~S}+$
$\mathrm{S}^{\circ}$
$2 \mathrm{CuFe}_{2} \mathrm{~S}_{3}+\mathrm{Cu}_{2} \mathrm{~S}$
$\rightarrow \quad 0.8 \mathrm{Cu}_{5} \mathrm{FeS}_{4}$
$3.2 \mathrm{FeS}+0.6 \mathrm{~S}^{\circ}$
$7 \mathrm{FeS}_{2}$

$$
\mathrm{Fe}_{7} \mathrm{~S}_{8}+6 \mathrm{~S}^{\circ}
$$

\section{$\rightarrow$}

The sample percentage weight loss obtained during the chlorination of sulfides using boat experiments is an algebraic sum of those due to the partial thermal decomposition of sulfides, chlorides' formation, and chlorides' volatilization. Figure 7 gives an example of the HGC treatment between $335{ }^{\circ} \mathrm{C}$ and $780{ }^{\circ} \mathrm{C}$. It was observed that fractions of the sample were lost during the sample heating under nitrogen atmosphere at temperatures higher or equal to $475{ }^{\circ} \mathrm{C}$, prior to the chlorination. This is due to the fact that chalcopyrite and pyrite undergo thermal transformation $\left.{ }^{2}\right]$ as described by Eqs. [1] through [3]. On the other hand, the initial weight gain of HGC sample, during its chlorination, decreases with the increase of the chlorination temperature. 
The formation of eutectics of low melting points between different chlorides, such as $\mathrm{CuCl}-\mathrm{FeCl}_{3}{ }^{[1]}$, led to complexity of the sulfides' chlorination. Another example is the chlorination of $\mathrm{PbS}$. Lower chlorination extent of $\mathrm{PbS}$ was achieved at $450{ }^{\circ} \mathrm{C}$ than at $400{ }^{\circ} \mathrm{C}$ (refer to Figure 5). To clarify this phenomenon, two TGA tests of $\mathrm{PbS}$ chlorination using $\mathrm{Cl}_{2}+\mathrm{N}_{2}$ were performed at $400{ }^{\circ} \mathrm{C}$ and $450{ }^{\circ} \mathrm{C}$ and the results are given in Figure 8. The initial reaction rate of the $\mathrm{PbS}$ chlorination at $450{ }^{\circ} \mathrm{C}$ is quite rapid, then the reaction seems to be stopped. While at $400{ }^{\circ} \mathrm{C}$, about full chlorination of $\mathrm{PbS}$ was achieved. The XRD results of the chlorination residues are reported in Figure 9. Only $\mathrm{PbCl}_{2}$ was revealed in the residue of chlorination at $400{ }^{\circ} \mathrm{C}$, while $\mathrm{PbS}$ remained as a main phase, besides $\mathrm{PbCl}_{2}$, in the residue obtained at $450{ }^{\circ} \mathrm{C}$. Lower $\mathrm{PbS}$ chlorination extent at $450{ }^{\circ} \mathrm{C}$ compared with that at $400{ }^{\circ} \mathrm{C}$ could be explained by the presence of an eutectic at $450{ }^{\circ} \mathrm{C}$ in the $\mathrm{PbCl}_{2}-\mathrm{PbS}$ system, as shown by Figure 10[5]. The formation of this liquid phase could probably decrease the reaction rate of $\mathrm{PbS}$ with chlorine at $450{ }^{\circ} \mathrm{C}$.

\section{Analysis of the Reaction Products of the Concentrates' Chlorination}

Systematic SEM, XRD, and chemical analysis of the reaction products of the two concentrates' chlorination at different temperatures were performed. Details of these analyses are available in Reference 6 . An overview of the most representative results will be given in the following paragraphs.

\section{SEM analysis}

Several SEM spectra of the chlorination residues of LGC and HGC between $20{ }^{\circ} \mathrm{C}$ and 300 ${ }^{\circ} \mathrm{C}$ are given in Figure 11. The presence of chlorine in the LGC and HGC residues obtained at room temperature indicate that chlorine had reacted with the sulfides' concentrates. The peak intensity of sulfur decreased with temperature rise, while that of chlorine increased. At $300{ }^{\circ} \mathrm{C}$, SEM analysis showed that the residues obtained from both concentrates were sulfur-free indicating that full chlorination of the sulfides was achieved. On the other hand, the $\mathrm{HGC}$ residue obtained at $300{ }^{\circ} \mathrm{C}$ was almost iron-free indicating that iron was removed as ferric chloride. However, iron was detected in the LGC residue at $300{ }^{\circ} \mathrm{C}$. This is probably due to the unreacted iron found in clinochlore : $(\mathrm{Mg}, \mathrm{Fe})_{6}(\mathrm{Si}, \mathrm{Al})_{4} \mathrm{O}_{10}(\mathrm{OH})_{8}$.

Condensates of chlorination of both concentrates were significantly observed at temperatures higher than $200{ }^{\circ} \mathrm{C}$. Figure 12 shows some spectra from the condensates obtained during the chlorination of the LGC at temperatures of : $250{ }^{\circ} \mathrm{C}, 400{ }^{\circ} \mathrm{C}$, and $600{ }^{\circ} \mathrm{C}$. Similar spectra were obtained by the chlorination of HGC. Condensates were recovered at different condensation zone along the reactor (see Figure 3 for $\mathrm{C}_{1}$ and $\mathrm{C}_{2}$ ). These condensates were essentially composed of $\mathrm{Fe}$ and $\mathrm{Cl}$ for a chlorination temperature lower than $300{ }^{\circ} \mathrm{C}$ showing that iron was removed as $\mathrm{FeCl}_{3}$ which is characterized by a vapor pressure of about $1 \mathrm{~atm}$ at temperatures close to $300{ }^{\circ} \mathrm{C}$. At temperatures equal and higher than $400{ }^{\circ} \mathrm{C}$, copper was also detected in the condensate $\left(\mathrm{C}_{1}\right)$, and it 
was almost iron-free. Best separation of copper chlorides from ferric chloride was achieved during the chlorination at $600{ }^{\circ} \mathrm{C}$. This selective separation of condensates $\left(\mathrm{C}_{1}\right.$ and $\left.\mathrm{C}_{2}\right)$ was probably due to the natural temperature gradient of the condensation zone. Sulfur was not detected in the solid condensates regardless the chlorination temperature, indicating that sulfur was essentially removed as $\mathrm{S}_{\mathrm{X}} \mathrm{Cl}_{\mathrm{y}}\left(\mathrm{S}_{2} \mathrm{Cl}_{2}+\mathrm{SCl}_{2}\right)$ which have sufficiently high vapor pressures (see Figure 6) to be transported out by the exhaust gases. The formation of sulfur dichloride is probably due to high partial pressure of chlorine in the chlorination process.

\section{XRD analysis}

All residues of the LGC and HGC chlorination at temperatures ranging from $20{ }^{\circ} \mathrm{C}$ to 700 ${ }^{\circ} \mathrm{C}$ were subjected to XRD analysis. Figure 13 represents the diffractograms of some residues of LGC chlorination between $50{ }^{\circ} \mathrm{C}$ and $500{ }^{\circ} \mathrm{C}$. They confirm the decrease of $\mathrm{CuFeS}_{2}$ and $\mathrm{FeS}_{2}$ peaks' intensity and increase of ray intensities of $\mathrm{CuCl}_{2}$. Cupric chloride was identified as a mixture of $\mathrm{CuCl}_{2}$ and $\mathrm{CuCl}_{2} \cdot 2 \mathrm{H}_{2} \mathrm{O}$ due to the hygroscopic nature of $\mathrm{CuCl}_{2}$. Ferric chloride was not revealed by XRD analysis, but its presence in the chlorination residues at lower temperatures was confirmed earlier by TG analysis[1]. No sulfides were detected in the chlorination residue obtained at $300{ }^{\circ} \mathrm{C}$. Clinochlore was decomposed at temperatures closer to $500{ }^{\circ} \mathrm{C}$. However, the decomposition products were not identified.

Figure 14 gives similar results concerning the HGC residues' chlorination. Chlorination residue at $300{ }^{\circ} \mathrm{C}$ was essentially composed of copper, lead, and zinc chlorides. However, $\mathrm{ZnCl}_{2}$ was not detected by XRD analysis because of its amorphous nature. The presence of $\mathrm{CuCl}$ besides $\mathrm{CuCl}_{2}$ at higher temperatures was confirmed by XRD. Although the decomposition of $\mathrm{CuCl}_{2}$ into $\mathrm{CuCl}$ occurs at about $537^{\circ} \mathrm{C}[7]$, its only partial decomposition is due to the high partial pressure of chlorine in the chlorination process.

A summary of the phases identified by XRD analysis in the residues obtained at different chlorination temperatures for LGC and HGC is given in Table II and III, respectively. As shown by Table II, the chlorination residue of LGC at $300{ }^{\circ} \mathrm{C}$ is composed of $\mathrm{CuCl}_{2}$, clinochlore and quartz. Higher temperatures of the chlorination allow the decomposition of clinochlore, volatilization and/or decomposition of $\mathrm{CuCl}_{2}$. Similarly, the $\mathrm{HGC}$ residue obtained at $300{ }^{\circ} \mathrm{C}$ is sulfide-free (Table III) and contains the valuable metals as chlorides.

Although the condensates were subjected to XRD analysis, it was observed that they are generally amorphous, consequently no observation is available on the phases present in the condensates. However, the presence of iron in the condensates at lower temperatures suggests that it was volatilized as $\mathrm{FeCl}_{3}$ since the boiling point of $\mathrm{FeCl}_{2}$ is $1026{ }^{\circ} \mathrm{C}[4]$. Copper is probably removed partially as $\mathrm{CuCl}_{2}$ at lower temperatures and as $\mathrm{CuCl}_{2}+\mathrm{Cu}_{3} \mathrm{Cl}_{3}{ }^{[7]}$ at higher temperatures. 
Table II. Phases Identified by XRD in the LGC Chlorination Residues between $20{ }^{\circ} \mathrm{C}$ and $700{ }^{\circ} \mathrm{C}$.

\begin{tabular}{|c|c|c|c|c|c|c|c|c|c|c|c|c|}
\hline Phases & Raw & $20^{\circ} \mathrm{C}$ & 50 & 100 & 150 & 200 & 250 & 300 & 400 & 500 & 600 & $700^{\circ} \mathrm{C}$ \\
\hline $\mathrm{CuFeS}_{2}$ & & & & & & & & & & & & \\
\hline $\mathrm{CuCl}_{2}$ & & & & & & & & & & & & \\
\hline $\mathrm{CuCl}$ & & & & & & & & & & & & \\
\hline $\mathrm{FeS}_{2}$ & & & & & & & & & & & & \\
\hline $\mathrm{FeCl}_{3} *$ & & & & & & & & & & & & \\
\hline Clinochlore & & & & & & & & & & & & \\
\hline $\mathrm{SiO}_{2}$ & & & & & & & & & & & & \\
\hline
\end{tabular}

Table III. Phases Identified by XRD in the HGC Chlorination Residues between $20^{\circ} \mathrm{C}$ and $700{ }^{\circ} \mathrm{C}$.

\begin{tabular}{|c|c|c|c|c|c|c|c|c|c|c|c|c|}
\hline Phases & Raw & $20^{\circ} \mathrm{C}$ & 50 & 100 & 150 & 200 & 250 & 300 & 400 & 500 & 600 & $700{ }^{\circ} \mathrm{C}$ \\
\hline \multicolumn{13}{|l|}{$\mathrm{CuFeS}_{2}$} \\
\hline \multicolumn{13}{|l|}{$\mathrm{CuCl}_{2}$} \\
\hline \multicolumn{13}{|l|}{$\mathrm{CuCl}$} \\
\hline \multicolumn{13}{|l|}{$\mathrm{FeS}_{2} *$} \\
\hline \multicolumn{13}{|l|}{$\mathrm{FeCl}_{3} * *$} \\
\hline \multicolumn{13}{|l|}{ Pb-comp. $* * *$} \\
\hline \multicolumn{13}{|l|}{$\mathrm{PbCl}_{2}$} \\
\hline \multicolumn{13}{|l|}{$\mathrm{ZnS}$} \\
\hline \multicolumn{13}{|l|}{$\mathrm{ZnCl}_{2}$} \\
\hline & & entifie & las & & & & roba & phase & & & & \\
\hline
\end{tabular}

\section{Chemical analysis}

The qualitative analyses such as SEM and XRD indicated that, in our conditions, the temperatures close to $300{ }^{\circ} \mathrm{C}$ were adequate for the full chlorination of sulfides contained in both concentrates and for the volatilization of sulfur and iron chlorinated-compounds. In order to check on this hypothesis, iron and copper contents of the chlorination residues were determined by chemical analysis.

Figure 15 is a data compilation of the chlorination of LGC between $20^{\circ} \mathrm{C}$ and $600{ }^{\circ} \mathrm{C}$. Iron extraction was remarkable from $200{ }^{\circ} \mathrm{C}$ but it was not complete at $300{ }^{\circ} \mathrm{C}$. Iron not removed at 300 ${ }^{\circ} \mathrm{C}$ corresponds to the iron present as an oxide in the clinochlore. Full extraction of iron could be achieved at temperatures higher than $500{ }^{\circ} \mathrm{C}$ when the clinochlore was decomposed. Copper extraction became significant at temperature higher than $400{ }^{\circ} \mathrm{C}$ and about 75 pct of copper were extracted at $600{ }^{\circ} \mathrm{C}$. The PWL curve described in Figure 15 for the LGC chlorination are in good agreement with the extraction extents of iron from $200{ }^{\circ} \mathrm{C}$ and of copper from about $350{ }^{\circ} \mathrm{C}$. On the other hand, the calculated limit $\left(\mathrm{L}_{1}\right)$ for selective chlorination of LGC is fairly consistent with the PWL of the LGC sample and with the results of chemical analysis of the residue obtained at $300{ }^{\circ} \mathrm{C}$. 
Results of chemical analysis concerning the extraction of iron and copper during the chlorination of $\mathrm{HGC}$ up to $600{ }^{\circ} \mathrm{C}$ are illustrated in Figure 16. Almost complete iron extraction was achieved at $300{ }^{\circ} \mathrm{C}$. This was possible because the iron of HGC is bore by the sulfides, essentially in the chalcopyrite. The selective chlorination limit $\left(\mathrm{L}_{2}\right)$ is fully consistent with the PWL and extraction extent of iron obtained at $300{ }^{\circ} \mathrm{C}$. The copper extraction started at higher temperatures than in the case of LGC and about 40 pct of copper were extracted at $600{ }^{\circ} \mathrm{C}$. This is probably due to the fact that the HGC residues were systematically agglomerated whilst those of LGC did not undergo such phenomenon. The presence of inert compounds in $\mathrm{LGC}$, such as $\mathrm{SiO}_{2}$, prevented the agglomeration of the residues.

The agglomeration of the chlorination residues, essentially for HGC, was probably caused by the increase of temperature thanks to the exothermic nature of the sulfides' chlorination reactions. To confirm that, a series of the isothermal chlorination tests at $300{ }^{\circ} \mathrm{C}$ using 2 grams of LGC and HGC samples was performed. A gas mixture of $\mathrm{Cl}_{2}+\mathrm{N}_{2}$ with different chlorine contents and with a $\mathrm{V}_{\mathrm{g}} \approx 0.84 \mathrm{~cm} / \mathrm{s}$ was used. Figures 17 (a) and (b) plot the increases of temperature of LGC and HGC, respectively, during their chlorination under the above-mentioned conditions. As could be expected, the sample temperature increased with the increase of chlorine content in the gas mixture. In addition, the increase of temperature for HGC is higher than that of the LGC. This is supported by the fact that the HGC sulfides' content is higher than that of LGC one.

As shown by Figure 17, the increase of temperature was observed at the beginning of the chlorination. This may be explained by a rapid exothermic reaction of chlorine with sulfides followed by an endothermic volatilization of species such as $\mathrm{S}_{\mathrm{x}} \mathrm{Cl}_{\mathrm{y}}$ and $\mathrm{FeCl}_{3}$. On the other hand, the chlorides formed at the surface of the sample covered the non reacted sample, and consequently, the remainder of the sample reacted then slower due to difficulties of chlorine to diffuse throughout the chlorides' layer.

\section{Effect of Other Parameters on the Chlorination of LGC and HGC}

As mentioned in the preceding sections, the chlorination of both concentrates was achieved for 2 hours at $300{ }^{\circ} \mathrm{C}$ by using an equimolar $\mathrm{Cl}_{2}+\mathrm{N}_{2}$ gas mixtures with a total gas flow rate of 40 $\mathrm{L} / \mathrm{h}$. It was worthwhile to check the effect of the reaction time, and simultaneously, the effect of chlorine content, gas flow rate, and reaction time on the complete chlorination of concentrates. The results are discussed in terms of how these parameters affect the percentage weight loss in order to reach the defined limits of the selective chlorination of each concentrate.

\section{Effect of reaction time}

This effect was studied between $175^{\circ} \mathrm{C}$ and $300{ }^{\circ} \mathrm{C}$ during the chlorination of LGC and $\mathrm{HGC}$ with $\mathrm{Cl}_{2}+\mathrm{N}_{2}\left(\mathrm{Cl}_{2} / \mathrm{N}_{2}=1\right)$. The reaction time was varied from 0.25 to 4 hours. Figures 18 (a) 
and (b) summarized the obtained results given as PWL versus temperatures at different reaction times. Only weight gains were observed for the chlorination of LGC for the temperatures lower than $225^{\circ} \mathrm{C}$ regardless the explored reaction times. As mentioned before, low vapor pressure of ferric chloride at this temperature was responsible for this weight gain. Temperatures of about 275 ${ }^{\circ} \mathrm{C}$ are necessary to reach the selective chlorination limit of LGC at reaction time of about $2 \mathrm{~h}$. While, a reaction time of about 1 hour is sufficient to allow the selective chlorination of LGC at 300 ${ }^{\circ} \mathrm{C}$. It was observed that the LGC chlorination residues were slightly agglomerated. Similarly observations, concerning the evolution of PWL versus temperature, were valid for the HGC chlorination (see Figure 18 (b)). However, the residues of HGC chlorination were significantly agglomerated. For the experimental tests resulting to the PWL lower than selective chlorination of HGC, it was observed that the sample surface was essentially composed of the chlorides, while the remainder of sample was the coated-non reacted and agglomerated sulfides' particles.

\section{Effect of chlorine content}

As temperatures closer to $300{ }^{\circ} \mathrm{C}$ were necessary to achieve the selective chlorination of both concentrates, tests to check the effects of chlorine contents of the $\mathrm{Cl}_{2}+\mathrm{N}_{2}$ gas mixtures at different gas flow rates and reaction times were performed at $300{ }^{\circ} \mathrm{C}$. Figure 19 represents the experimental results for the LGC chlorination. The effect of chlorine was significant for the chlorine content up to 40 pct in the $\mathrm{Cl}_{2}+\mathrm{N}_{2}$ gas mixture. Higher chlorine content did not improve the chlorination process at two reaction times and at the gas flow rate selected. Consequently, a $\mathrm{Cl}_{2}+\mathrm{N}_{2}$ gas mixture containing about $50 \mathrm{pct} \mathrm{Cl}_{2}$ could allow a selective chlorination of LGC at 300 ${ }^{\circ} \mathrm{C}$ during a reaction time of 1 hour.

Results concerning HGC chlorination for the conditions mentioned previously are given in Figure 20. Chlorination of HGC is more dependent on the chlorine content in the gas mixture especially at low reaction time. However, a gas mixture of $\mathrm{Cl}_{2}+\mathrm{N}_{2}$ containing about 50 pct $\mathrm{Cl}_{2}$ would be considered as appropriate for the chlorination of HGC, whilst the reaction time can be higher than 1 hour.

\section{E. Flow sheet of the Proposed Process}

Data collected from the chlorination of two chalcopyrite concentrates at different conditions using boat experiments indicated that it was possible to use a low temperature chlorination-volatilization process, at about $300{ }^{\circ} \mathrm{C}$, in order to separate selectively the valuable metals from the others. The flow-sheet of the proposed process is represented in Figure 21. Although the results obtained in this study focused only on the chlorination process, other steps are added in the flow-sheet based on the data found in the literature. According to this flow-sheet, the chalcopyrite concentrate is chlorinated at about $300{ }^{\circ} \mathrm{C}$ in a fixed bed for a reaction time 1 to 2 hours. The reaction time depends on the concentrate composition. 


$\begin{array}{rlll}2 / 7 \mathrm{CuFeS}_{2}(\mathrm{~s})+\mathrm{Cl}_{2}(\mathrm{~g}) & \rightarrow & 2 / 7 \mathrm{CuCl}_{2}(\mathrm{~s})+2 / 7 \mathrm{FeCl}_{3}(\mathrm{~g})+2 / 7 \mathrm{~S}_{2} \mathrm{Cl}_{2}(\mathrm{~g}) \\ 2 / 9 \mathrm{CuFeS}_{2}(\mathrm{~s})+\mathrm{Cl}_{2}(\mathrm{~g}) & \rightarrow & 2 / 9 \mathrm{CuCl}_{2}(\mathrm{~s})+2 / 9 \mathrm{FeCl}_{3}(\mathrm{~g})+4 / 9 \mathrm{SCl}_{2}(\mathrm{~g}) \\ 2 / 3 \mathrm{PbS}(\mathrm{s})+\mathrm{Cl}_{2}(\mathrm{~g}) & \rightarrow & 2 / 3 \mathrm{PbCl}_{2}(\mathrm{~s}) & +1 / 3 \mathrm{~S}_{2} \mathrm{Cl}_{2}(\mathrm{~g}) \\ 1 / 2 \mathrm{PbS}(\mathrm{s})+\mathrm{Cl}_{2}(\mathrm{~g}) & \rightarrow & 1 / 2 \mathrm{PbCl}_{2}(\mathrm{~s}) & +1 / 2 \mathrm{SCl}_{2}(\mathrm{~g}) \\ 2 / 3 \mathrm{ZnS}(\mathrm{s})+\mathrm{Cl}_{2}(\mathrm{~g}) & \rightarrow & 2 / 3 \mathrm{ZnCl}_{2}(\mathrm{~s}) & +1 / 3 \mathrm{~S}_{2} \mathrm{Cl}_{2}(\mathrm{~g}) \\ 1 / 2 \mathrm{ZnS}(\mathrm{s})+\mathrm{Cl}_{2}(\mathrm{~g}) & \rightarrow & 1 / 2 \mathrm{ZnCl}_{2}(\mathrm{~s}) & \\ 2 / 5 \mathrm{FeS}_{2}(\mathrm{~s})+\mathrm{Cl}_{2}(\mathrm{~g}) & \rightarrow & & \end{array}$

Based on the experimental results and on the analysis of the reaction products, the main reaction of the sulfides contained in both concentrates with the chlorine at about $300{ }^{\circ} \mathrm{C}$ will be those described by Eqs. [4] to [11]. As mentioned previously, the gangue (quartz and clinochlore) was expected to be refractory in chlorine at $300{ }^{\circ} \mathrm{C}$.

The gas-phase of the concentrates' chlorination is composed essentially of iron and sulfur chlorides. Ferric chloride is recovered by cooling the gas phase at room temperature. The obtained ferric chloride can be treated in oxygen ${ }^{[8,9]}$ to give hematite and chlorine. The last will be recycled to the chalcopyrite chlorination unit after a composition adjustment. In addition, ferric chloride can be used as chlorinating agent ${ }^{[10]}$. As mentioned in the literature $[7,11,12]$, sulfur monochloride reacted with several sulfides producing metal chlorides and elementary sulfur. Thus, a second chlorination unit can be added in the proposed flow-sheet using sulfur chlorides as chlorinating agent. However, the sulfur chlorides obtained after their condensation, could also be subjected to hydrolysis and/or to reduction by hydrogen in order to recover elementary sulfur[13].

The chlorination residue will be leached with slightly acidified water at an adequate temperature in order to dissolve the chlorides of $\mathrm{Cu}, \mathrm{Zn}$, and $\mathrm{Pb}$. The insoluble solids (quartz and clinochlore) are expected to be not dangerous for the environment and could be landfilled. Other hydrometallurgical treatments will be required to recover selectively these metals.

Although the chlorination process was conduced at lower temperature compared with conventional pyrometallurgical ones, the problems related to the equipment's corrosion, the difficulties to proceed in a continuous system, etc. have to be taken into account once calculating the global cost of using the suggested process at industrial scale. 


\section{CONCLUSIONS}

The chlorination of LGC and HGC concentrates started from room temperature and full chlorination of sulfides was achieved at about $300{ }^{\circ} \mathrm{C}$ for a reaction time less or equal to 2 hours. At this temperature, the valuable metals are concentrated in the chlorination residues as $\mathrm{CuCl}_{2}, \mathrm{PbCl}_{2}$ and $\mathrm{ZnCl}_{2}$. Iron and sulfur chlorinated-compounds were fully volatilized. The selectivity of the chlorination process was assured by the wide difference on the vapor pressure between the chlorides of valuable metals and those of sulfur and iron.

Chlorination of both concentrates is exothermic leading to the possibility of developing of the process with a reduced external energy supply. However, the exothermic nature of the chlorination reaction as well as the presence of low temperature eutectics in different chloridechloride and/or sulfide-chloride systems will lead to some technical difficulties during the chlorination process.

The chlorination of both concentrates at temperatures higher than $350{ }^{\circ} \mathrm{C}$ leads to a partial volatilization of valuable metals' chlorides. Consequently, accurate cooling of the gas phase will be probably necessary for the selective separation of these chlorides. Cupric chloride is decomposed into cuprous one at temperatures higher than $500{ }^{\circ} \mathrm{C}$. At this temperature, clinochlore could be also decomposed. Therefore, the best temperature for the chlorination of both concentrates was chosen to be at about $300{ }^{\circ} \mathrm{C}$.

As the study was performed with several grams of the sample, more investigations at large experimentation will be necessary to validate the use of the low temperature chlorinationvolatilization process for the treatment of chalcopyrite concentrates.

\section{ACKNOWLEDGMENTS}

This work was performed in the frame of contract $\mathrm{N}^{\circ}$ BRE2-CT92-0173 thanks to the financial support of the European Union (DG-XII). The authors thank Dr. H. L. Schmidt for discussion, suggestion and help. They also would like to thank Dr. J. C. Mugica (INASMET, San Sebastian, Spain) and Dr. M. Coelho (INETI, Lisbon, Portugal) for providing samples and technical discussions. Authors are indebted to Dr. A. Bonazébi, Dr. M. Djona, Dr. S. Ivanaj, Dr. N. Menad and Dr. N. Mirghaffari for discussions and help on different subjects and to Mrs. C. Richard for technical and administrative support. 


\section{REFERENCES}

1 N. Kanari, I. Gaballah, E. Allain, and N. Menad: Metall. Mater. Trans. B., 1999, vol. 30B, pp. 567-576.

2 I. Gaballah, E. Allain, M.-Ch. Meyer-Joly, and K. Malau: Metall. Mater. Trans. B., 1994, vol. 25B, pp. 193-205.

3 N. Kanari, I. Gaballah, and E. Allain: Metall. Mater. Trans. B., 1999, vol. 30B, pp. 577-587.

4 Handbook of Chemistry and Physics, 74th edition, Boca Raton, New York, London, Tokyo, 1993-94, Edited by D.R. Lide, pp. 6-68 to 6-70.

5 E.M. Levin, C.R. Robbins, and H.F. McMurdie: in Phase Diagrams for Ceramists, Reser M.K. ed., American Ceramic Society, Columbus, OH, 1985, vol. II, second printing, p. 375.

6 N. Kanari: Ph.D. Thesis, Institut National Polythechnique de Lorraine, Laboratoire Environnement et Mineralurgie, Nancy, France, November 1995, 209 pages.

7 R. Titi-Manyaka and I. Iwasaki: Trans. Soc. Mining Eng. AIME, 1976, vol. 260, pp. 282288.

8 A.W. Henderson, T.T. Campbell, and F.E. Block : Met. Trans., 1972, vol. 3, pp. 2579-2583.

9 J.I. Paige, G.B. Robidart, H.M. Harris, and T.T. Campbell: J. Met., 1975, 27(11), pp. 12-16.

10 E.A. von Hahn Hardwin, "Chlorination of copper, lead, zinc, iron, silver and gold" (U.S. patent, 4576 812, 18 March 1986), 4 pages.

11 A. Landsberg, A. Adams, and J.L. Schaller, "Chlorination Kinetics of Selected Metal Sulfides”, USBM RI 8002, United States Bureau of Mines, Washington, 1975, 15 pages.

12 E.A. Smith: J. Am. Chem. Soc., 1898, 20, pp. 289-293.

13 E. Allain, I. Gaballah, N. Kanari, and J. C. Mugica: Proceedings of the Symposium 'Sulfide Smelting'98 : Current and Future Practices', San Antonio, TX, 2/98, Edited by J. A. Asteljoki and R. L. Stephens, Published by TMS, pp. 187-196. 


\title{
Low Temperature Chlorination-Volatilization Process for the Treatment of Chalcopyrite Concentrates
}

\author{
N. KANARI, I. GABALLAH, and E. ALLAIN*
}

\section{Figure Captions}

Fig. 1 : Effect of the sample weight on the chlorination of a chalcopyrite concentrate at $300{ }^{\circ} \mathrm{C}$ with :

$$
\begin{aligned}
& \text { (a) : }\left(10 \% \mathrm{Cl}_{2}\right)+\mathrm{N}_{2}, \\
& \text { (b) }:\left(50 \% \mathrm{Cl}_{2}\right)+\mathrm{N}_{2}, \\
& \text { (c) }: 100 \% \mathrm{Cl}_{2} .
\end{aligned}
$$

Fig. 2 : Experimental set-up used for the chlorination.

Fig. 3 : Temperature profiles of the reaction area and the condensation zone of chlorides.

Fig. 4 : Effect of gas flow rate on the chlorination of two chalcopyrite concentrates.

Fig. 5 : Effect of temperature on the chlorination of two concentrates and their main sulfides.

Fig. 6 : Evolution of vapor pressure of several chlorides as a function of the temperature[4].

Fig. 7 : TGA of $\mathrm{HGC}$ in $\mathrm{Cl}_{2}+\mathrm{N}_{2}$ gas mixture between $335^{\circ} \mathrm{C}$ and $780{ }^{\circ} \mathrm{C}$.

Fig. 8 : TGA of $\mathrm{PbS}$ in $\mathrm{Cl}_{2}+\mathrm{N}_{2}$ gas mixture at $400{ }^{\circ} \mathrm{C}$ and $450{ }^{\circ} \mathrm{C}$.

Fig. 9 : Results of XRD analysis of the residues obtained during the treatment of $\mathrm{PbS}$ in $\mathrm{Cl}_{2}+\mathrm{N}_{2}$ gas mixture at $400{ }^{\circ} \mathrm{C}$ and $450{ }^{\circ} \mathrm{C}$.

Fig. 10 : Phase diagram of $\mathrm{PbCl}_{2}-\mathrm{PbS}$ system ${ }^{[5]}$.

Fig. 11 : Results of SEM analysis of the residues obtained during the chlorination of LGC and HGC between $20^{\circ} \mathrm{C}$ and $300{ }^{\circ} \mathrm{C}$.

Fig. 12 : Results of SEM analysis of the condensates obtained during the chlorination of LGC at different temperatures.

Fig. 13 : Results of XRD analysis of the LGC chlorination residues obtained at different temperatures.

Fig. 14 : Results of XRD analysis of the HGC chlorination residues obtained at different temperatures.

Fig. 15 : Extraction of copper and iron from LGC during its chlorination at different temperatures.

Fig. 16 : Extraction of copper and iron from HGC during its chlorination at different temperatures.

Fig. 17 : Increase of temperature during the chlorination of (a) LGC and (b) $\mathrm{HGC}$ at $300{ }^{\circ} \mathrm{C}$ using different chlorine contents in the $\mathrm{Cl}_{2}+\mathrm{N}_{2}$ gas mixture.

Fig. 18 : Chlorination of (a) LGC and (b) $\mathrm{HGC}$ between $150{ }^{\circ} \mathrm{C}$ and $300{ }^{\circ} \mathrm{C}$ for different reaction times.

Fig. 19 : Chlorination of LGC at $300{ }^{\circ} \mathrm{C}$ using various chlorine contents in the gas mixture.

Fig. 20 : Chlorination of $\mathrm{HGC}$ at $300{ }^{\circ} \mathrm{C}$ using various chlorine contents in the gas mixture.

Fig. 21 : Suggested flow-sheet for the extraction of valuable metal chlorides by chlorination of chalcopyrite concentrates at low temperature. 

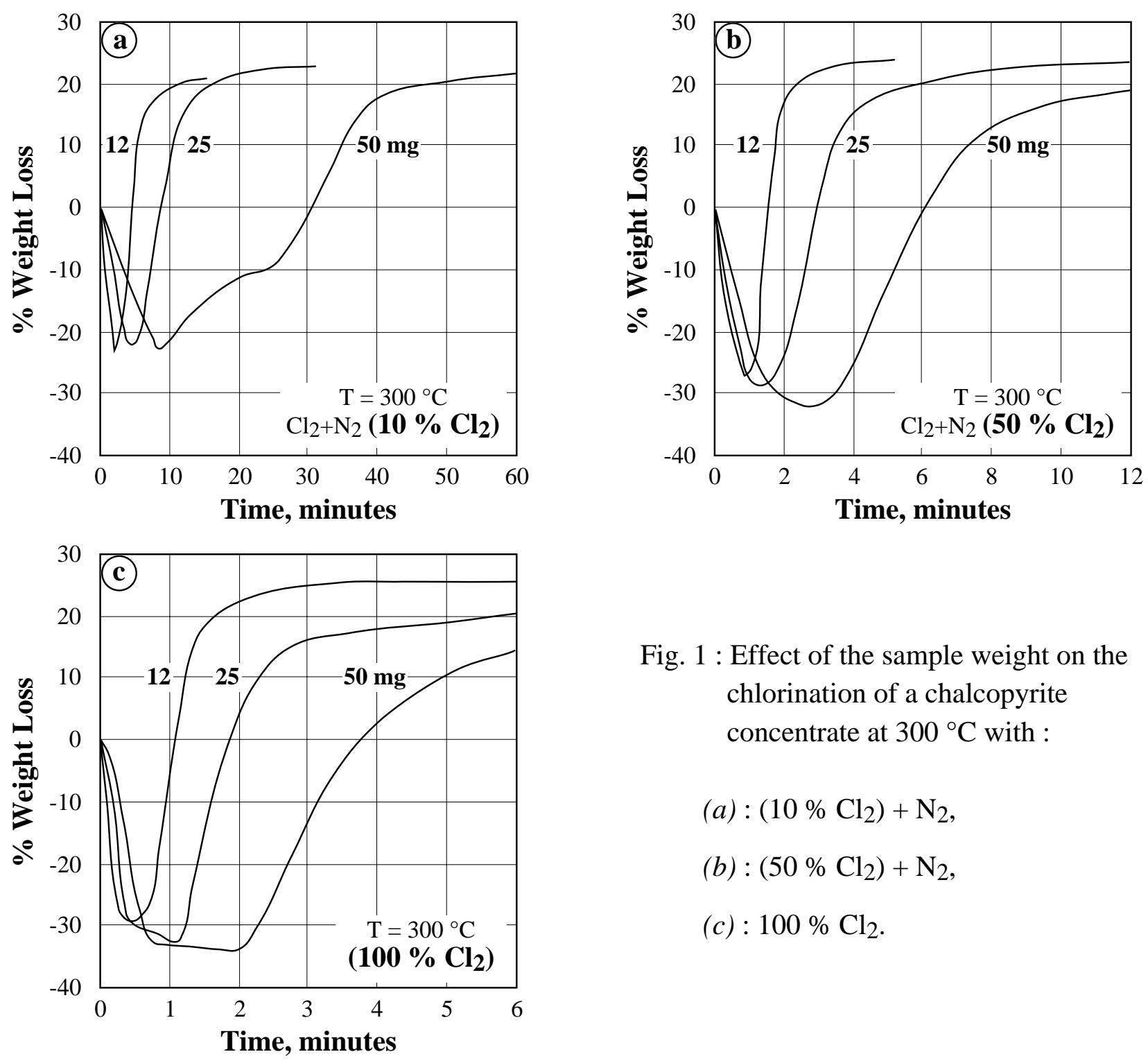

Fig. 1 : Effect of the sample weight on the chlorination of a chalcopyrite concentrate at $300{ }^{\circ} \mathrm{C}$ with :
(a) : $\left(10 \% \mathrm{Cl}_{2}\right)+\mathrm{N}_{2}$,
(b) : $\left(50 \% \mathrm{Cl}_{2}\right)+\mathrm{N}_{2}$,
(c) : $100 \% \mathrm{Cl}_{2}$.

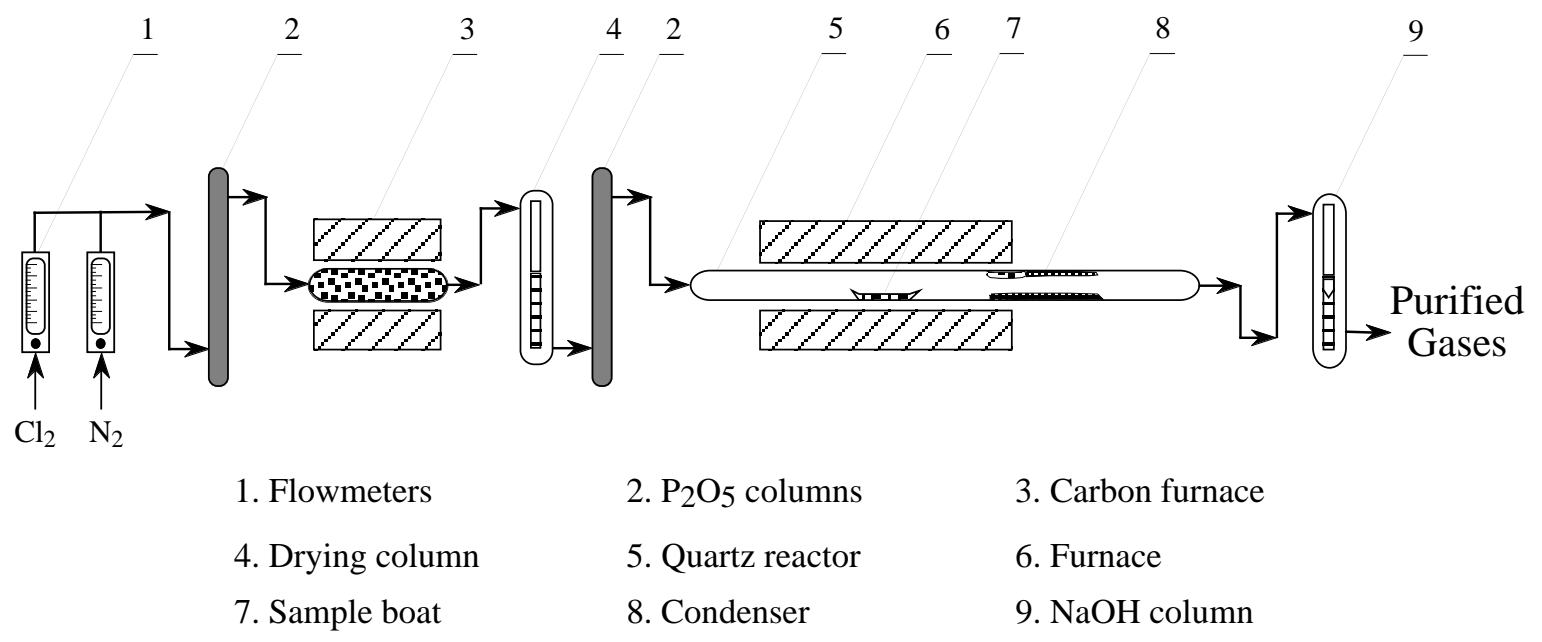

Fig. 2 : Experimental set-up used for the chlorination. 
(C1)

(C2)

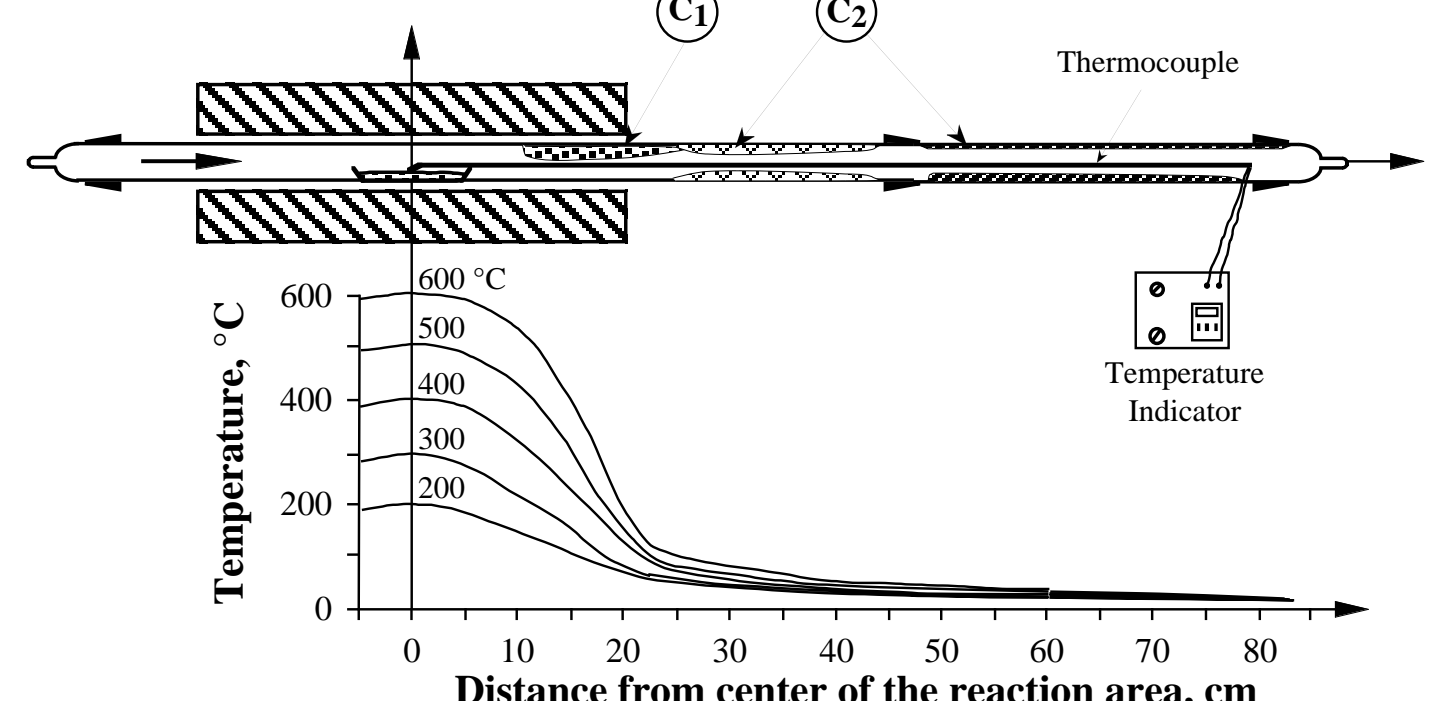

Distance from center of the reaction area, $\mathrm{cm}$

Fig. 3 : Temperature profiles of the reaction area and the condensation zone of chlorides.

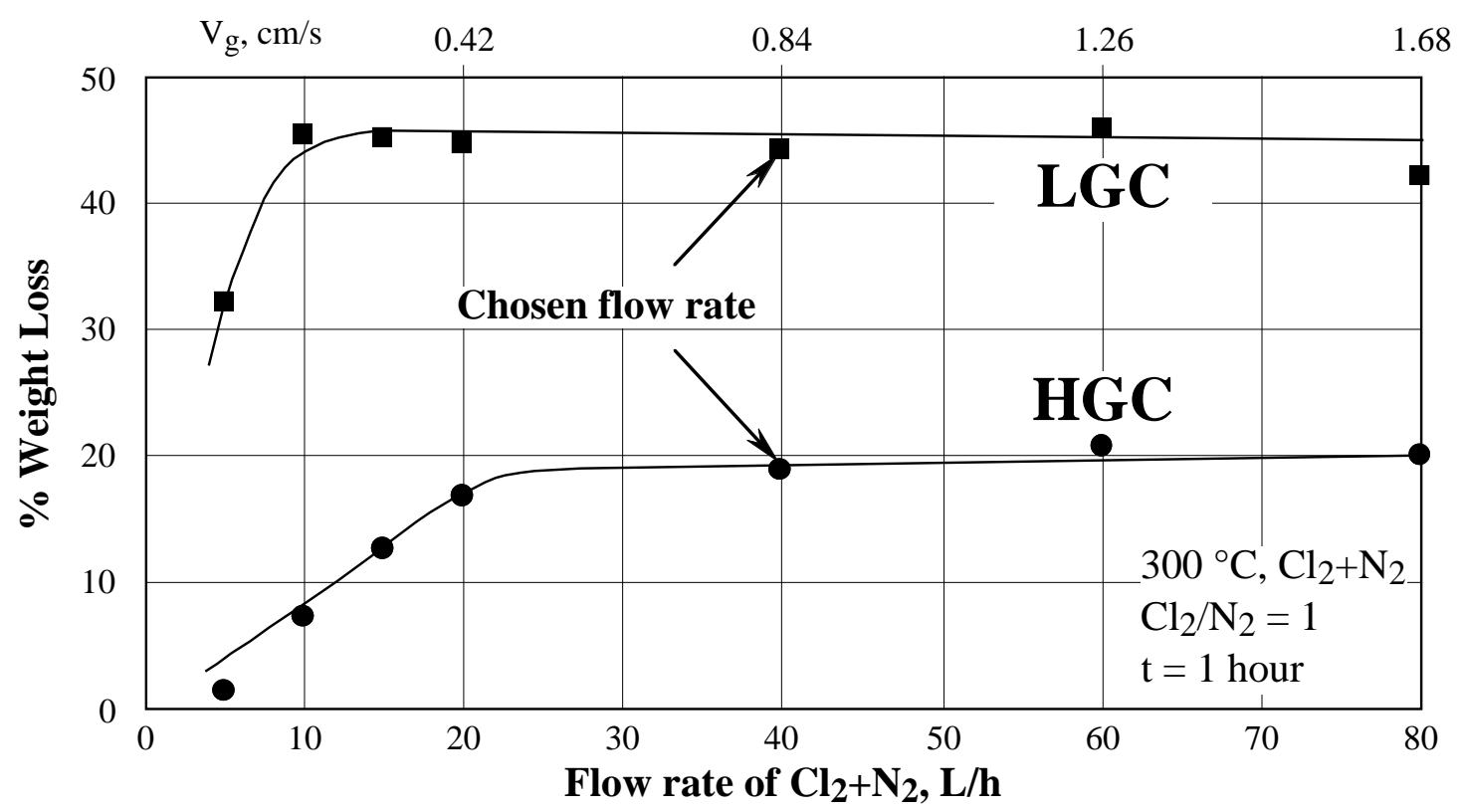

Fig. 4 : Effect of gas flow rate on the chlorination of two chalcopyrite concentrates. 


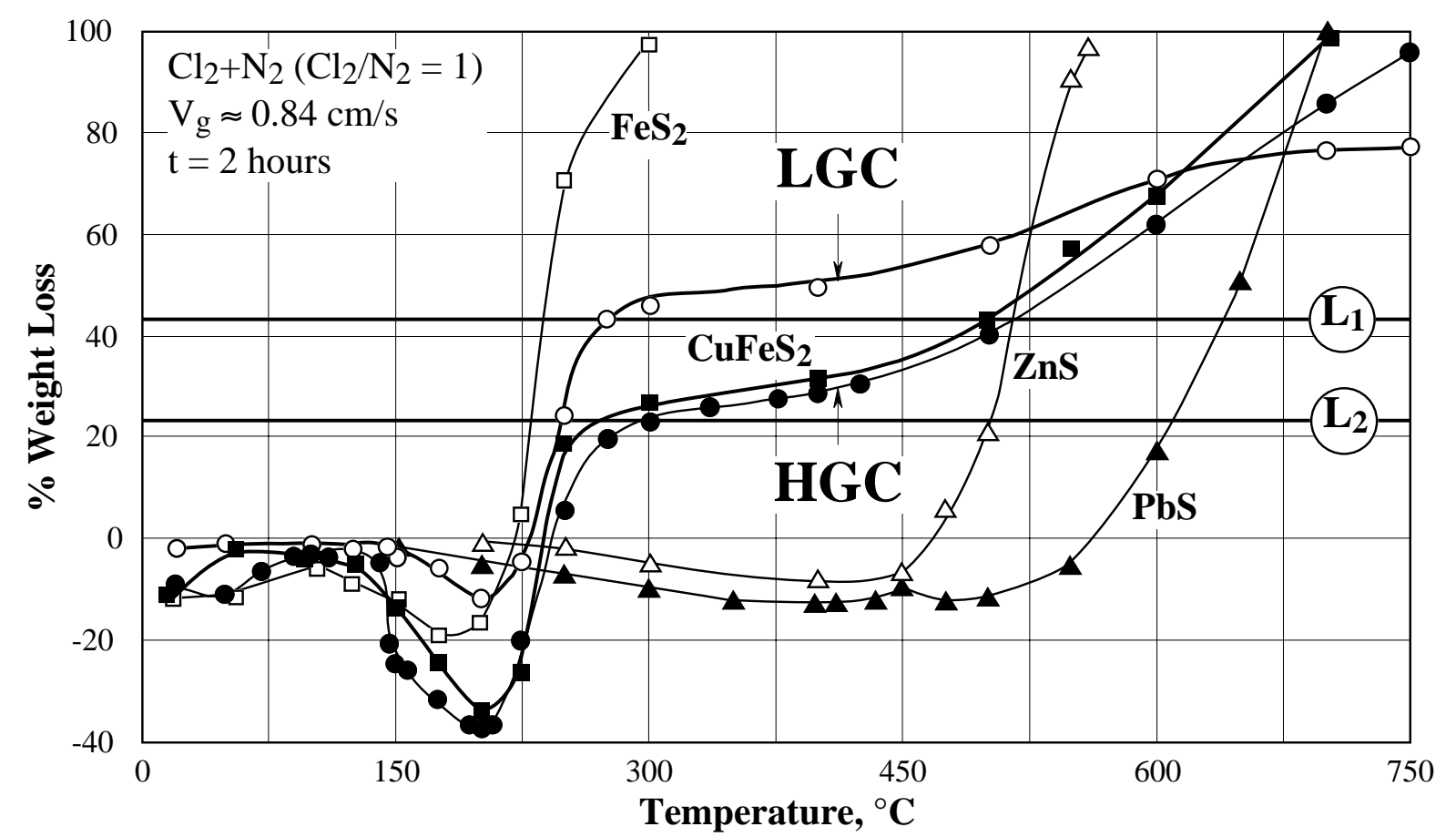

$\mathrm{L}_{1}$ :\% WL calculated for full chlorination of sulfides and volatilization of Fe and S chlorinated compounds for LGC, $\mathrm{L}_{2}$ : Idem for HGC.

Fig. 5 : Effect of temperature on the chlorination of two concentrates and their main sulfides.

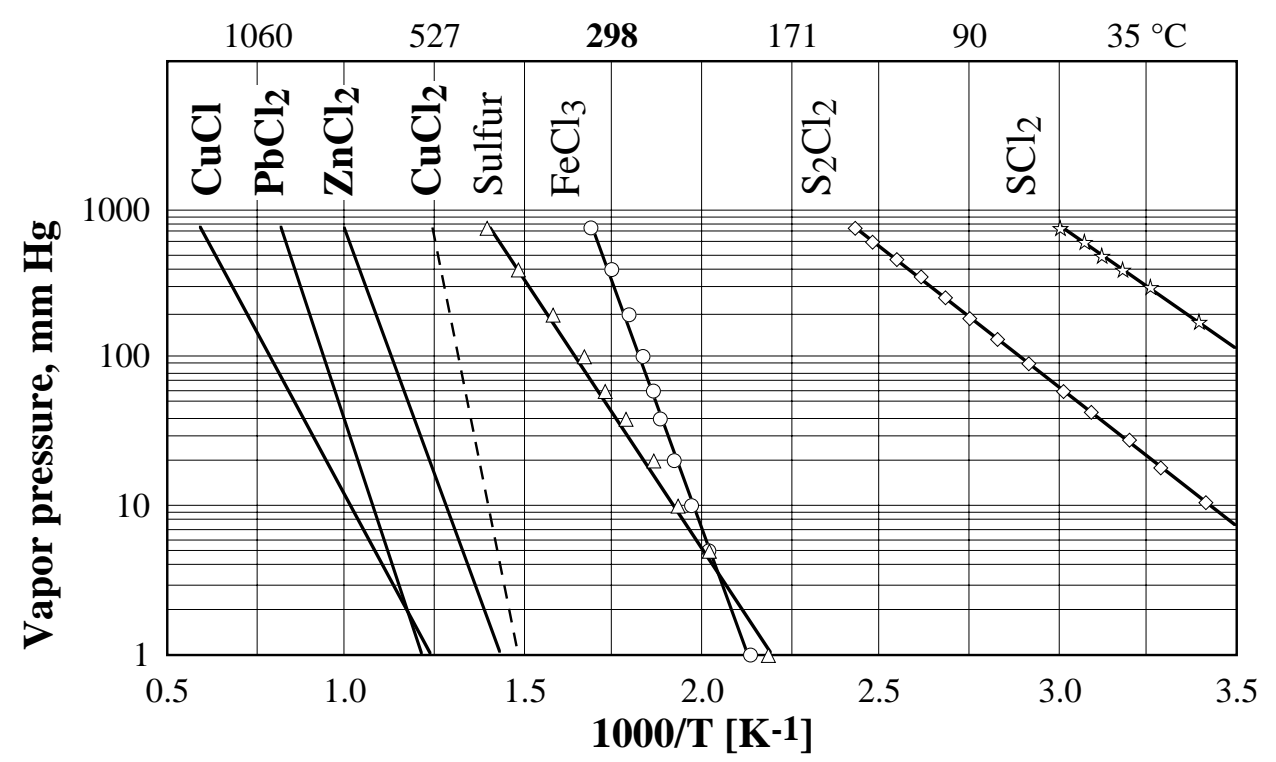

Fig. 6 : Evolution of vapor pressure of several chlorides as a function of the temperature[4]. 


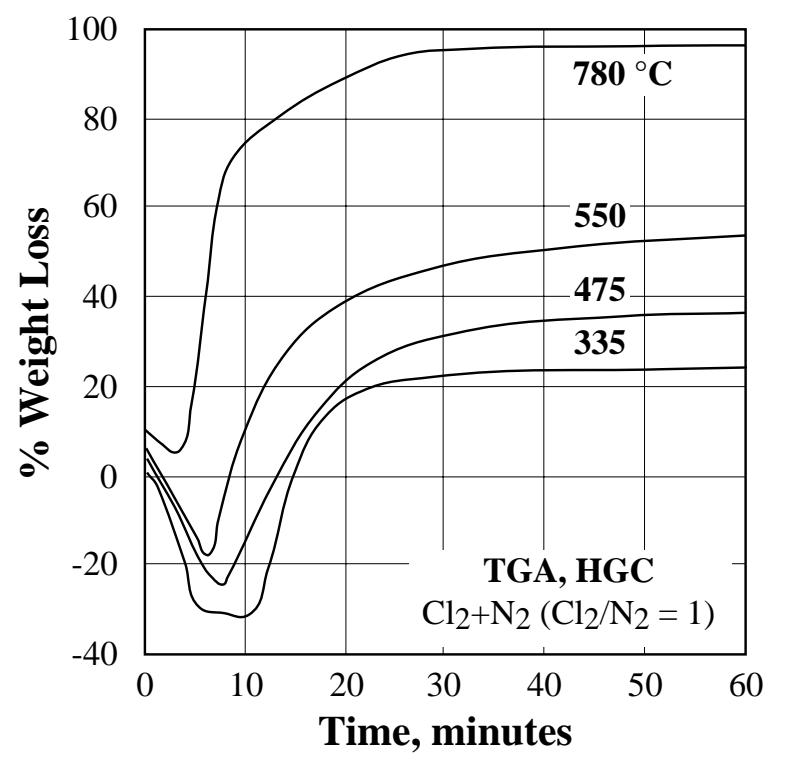

Fig. 7 : TGA of $\mathrm{HGC}$ in $\mathrm{Cl}_{2}+\mathrm{N}_{2}$ gas mixture between $335^{\circ} \mathrm{C}$ and $780{ }^{\circ} \mathrm{C}$.

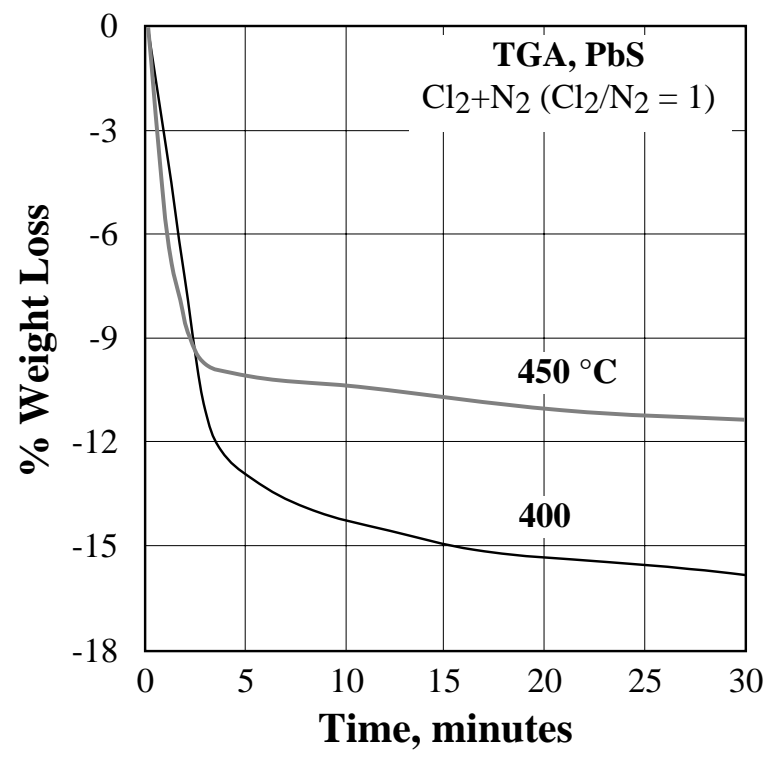

Fig. 8 : TGA of $\mathrm{PbS}$ in $\mathrm{Cl}_{2}+\mathrm{N}_{2}$ gas mixture at $400{ }^{\circ} \mathrm{C}$ and $450{ }^{\circ} \mathrm{C}$. 


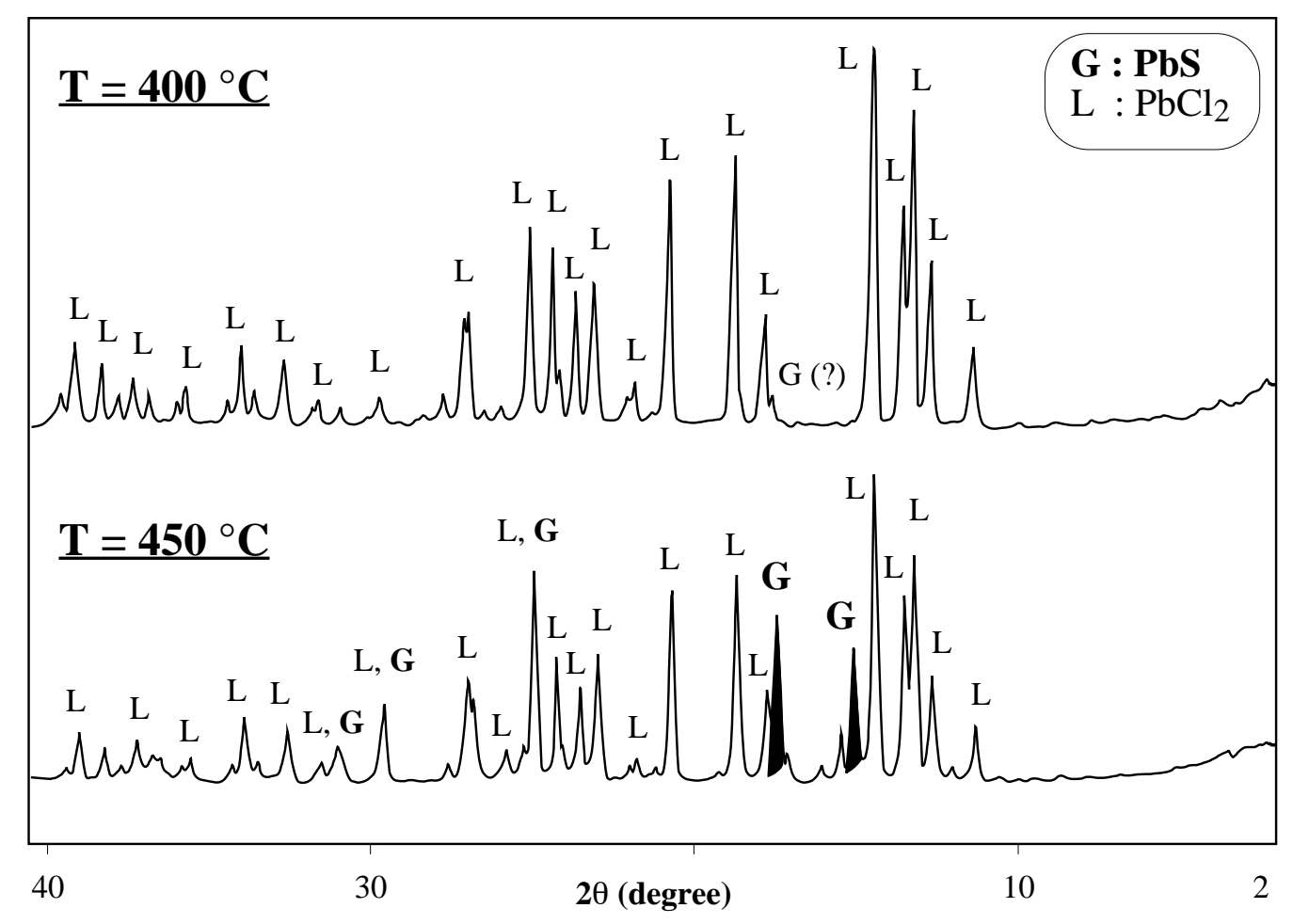

Fig. 9 : Results of XRD analysis of the residues obtained during the treatment of $\mathrm{PbS}$ in $\mathrm{Cl}_{2}+\mathrm{N}_{2}$ gas mixture at $400{ }^{\circ} \mathrm{C}$ and $450{ }^{\circ} \mathrm{C}$.

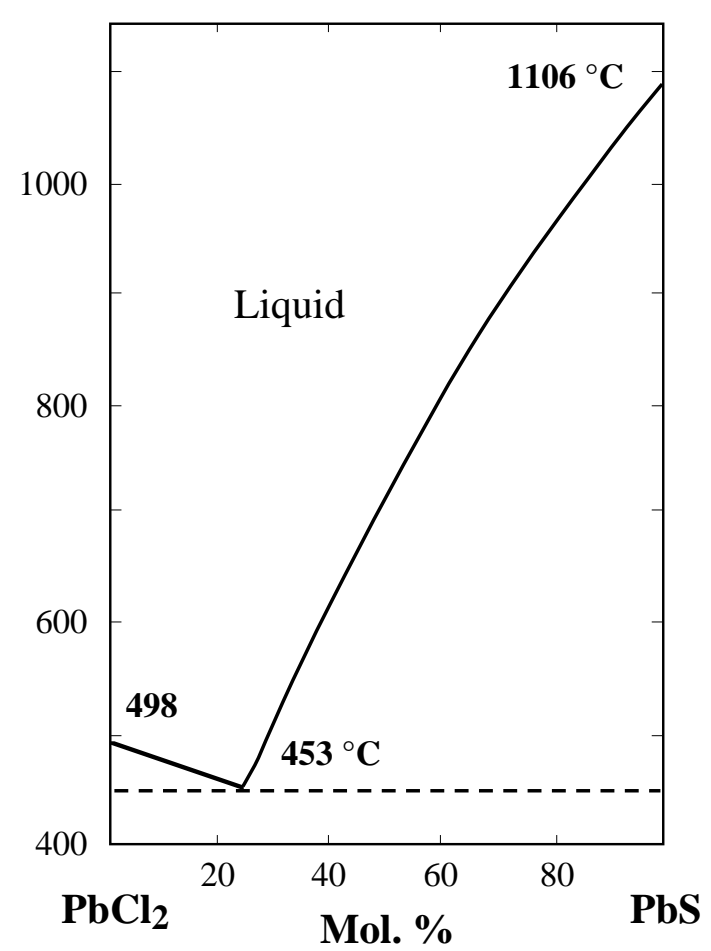

Fig. 10 : Phase diagram of $\mathrm{PbCl}_{2}-\mathrm{PbS}$ system[5]. 
Low Grade Concentrate (LGC)

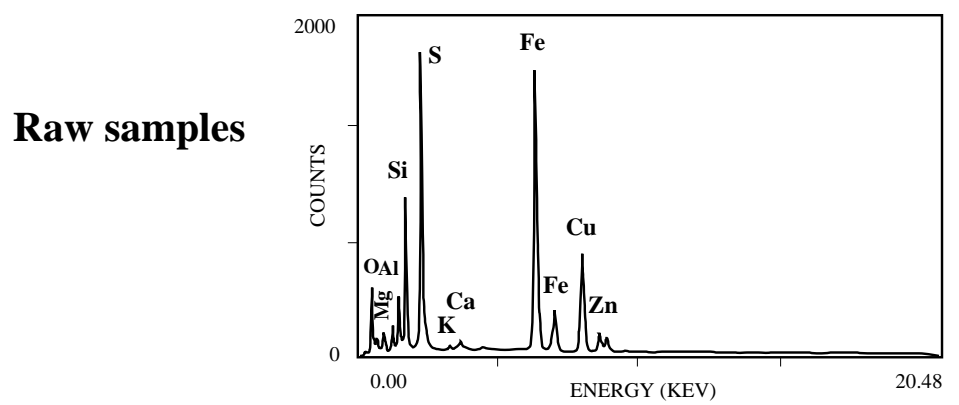

Treated at $\mathbf{T},{ }^{\circ} \mathrm{C}$

20

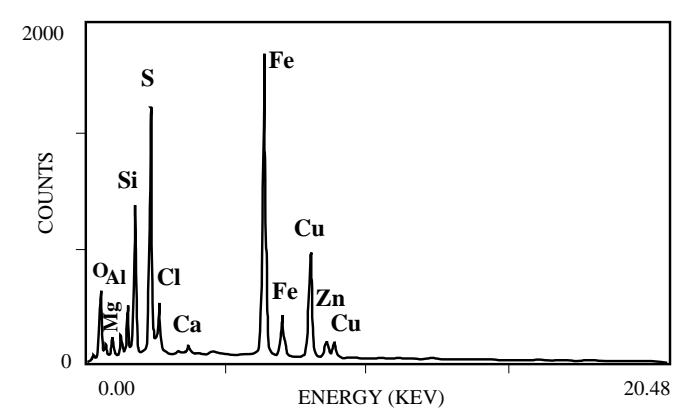

200
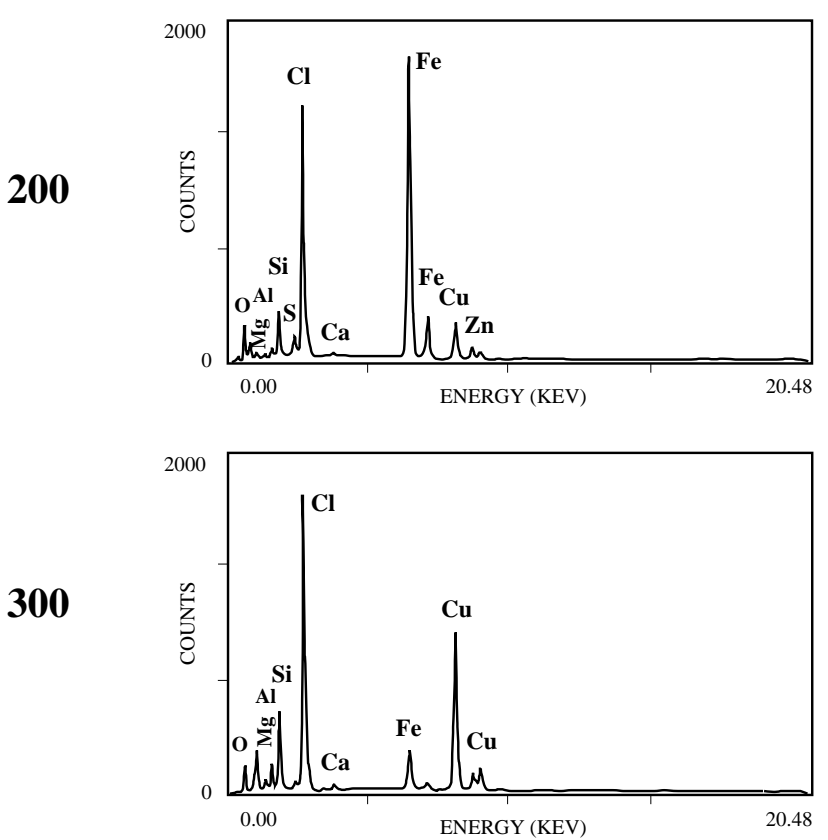

High Grade Concentrate (HGC)
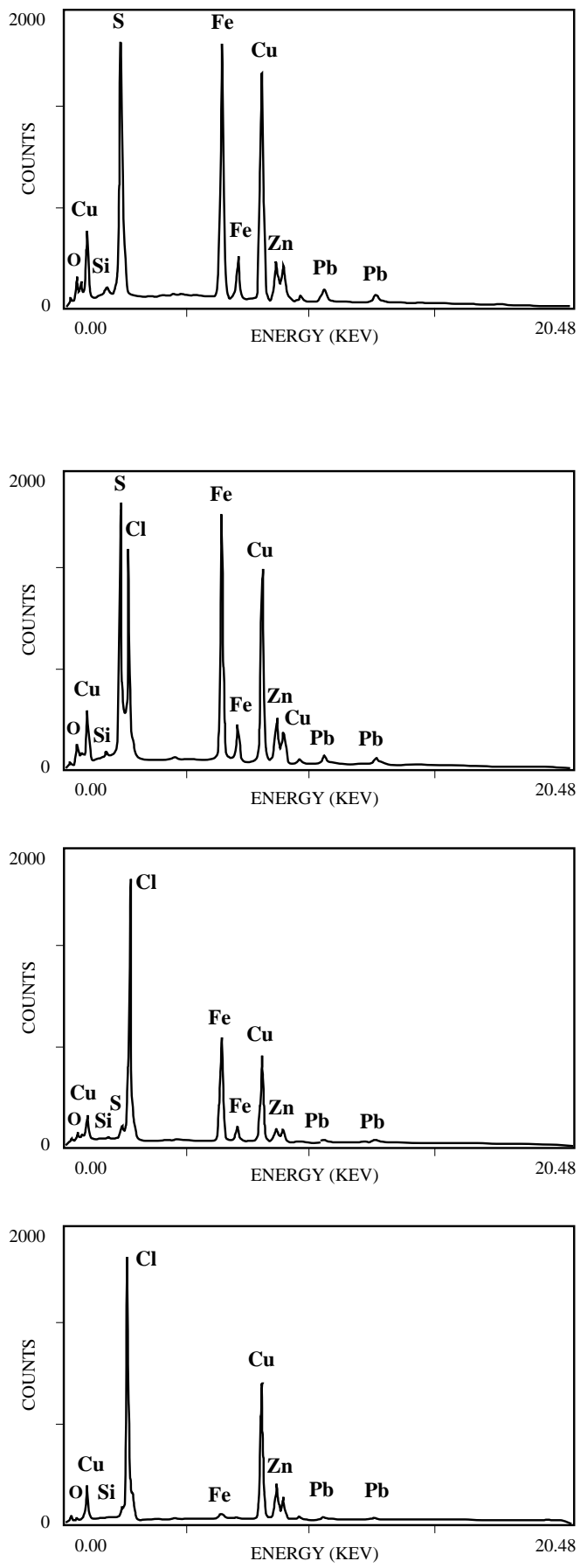

Fig. 11 : Results of SEM analysis of the residues obtained during the chlorination of LGC and HGC between $20^{\circ} \mathrm{C}$ and $300^{\circ} \mathrm{C}$. 

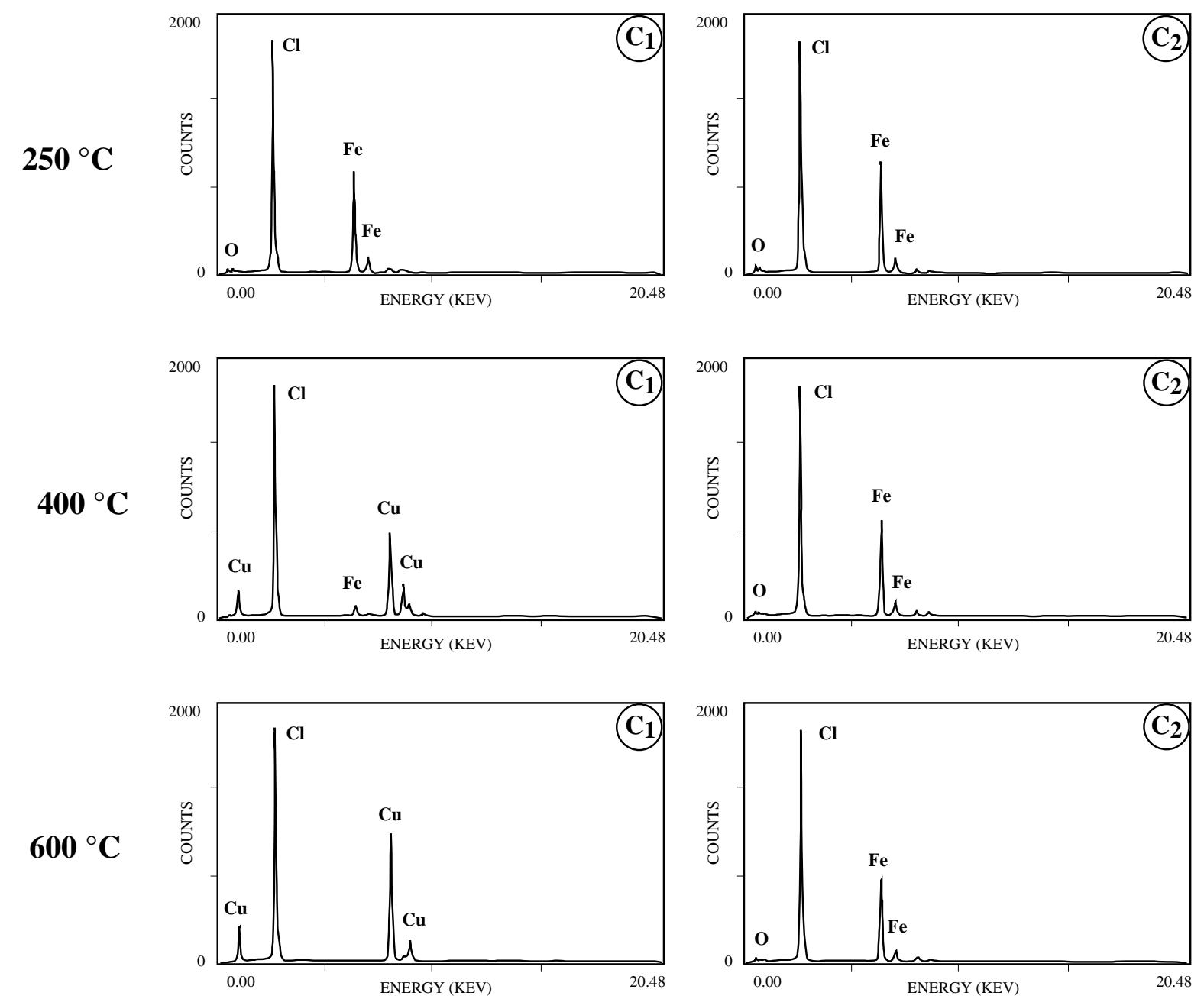

Fig. 12 : Results of SEM analysis of the condensates obtained during the chlorination of LGC at different temperatures. 


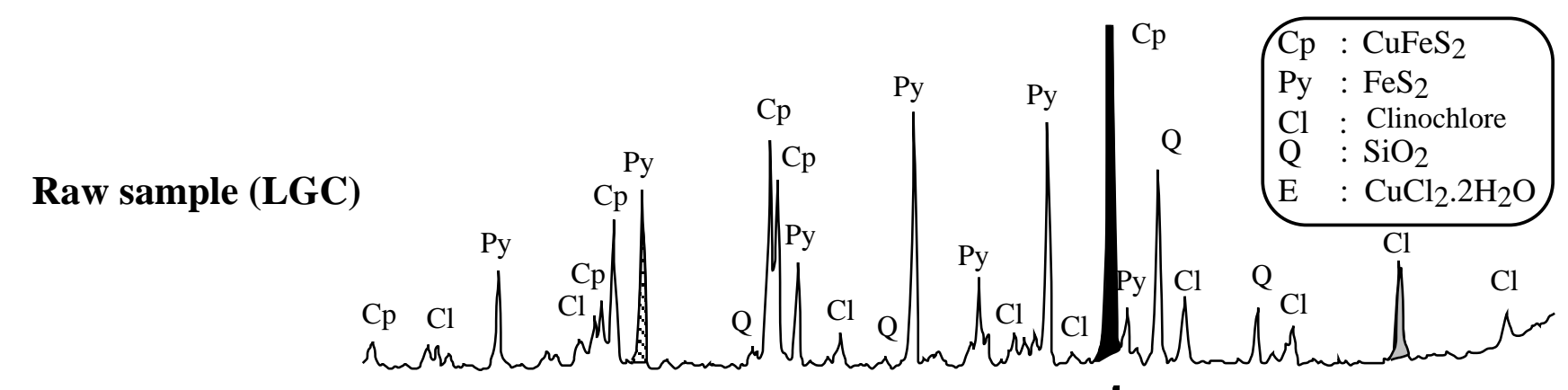

Treated at $\mathbf{T},{ }^{\circ} \mathrm{C}$

50

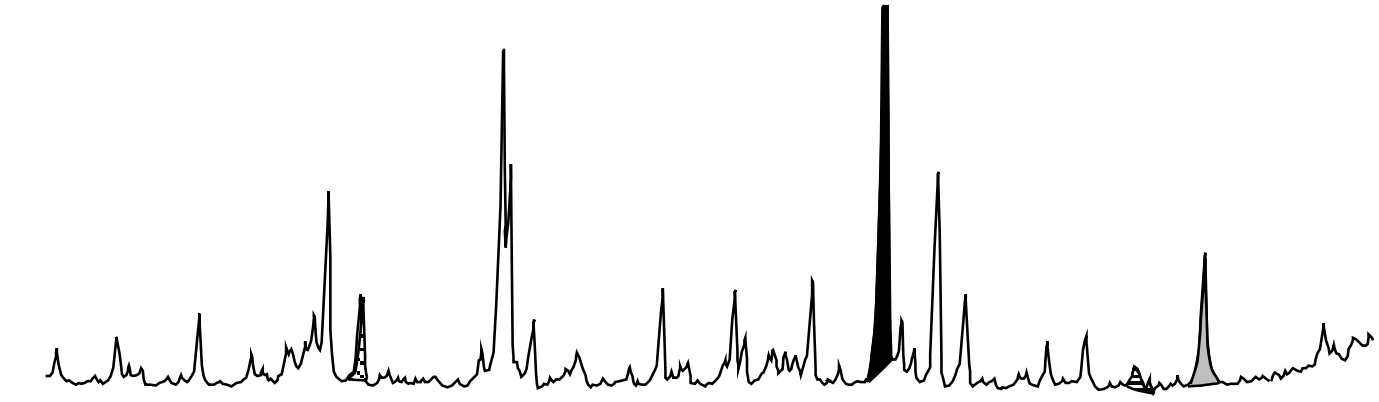

150

250

300
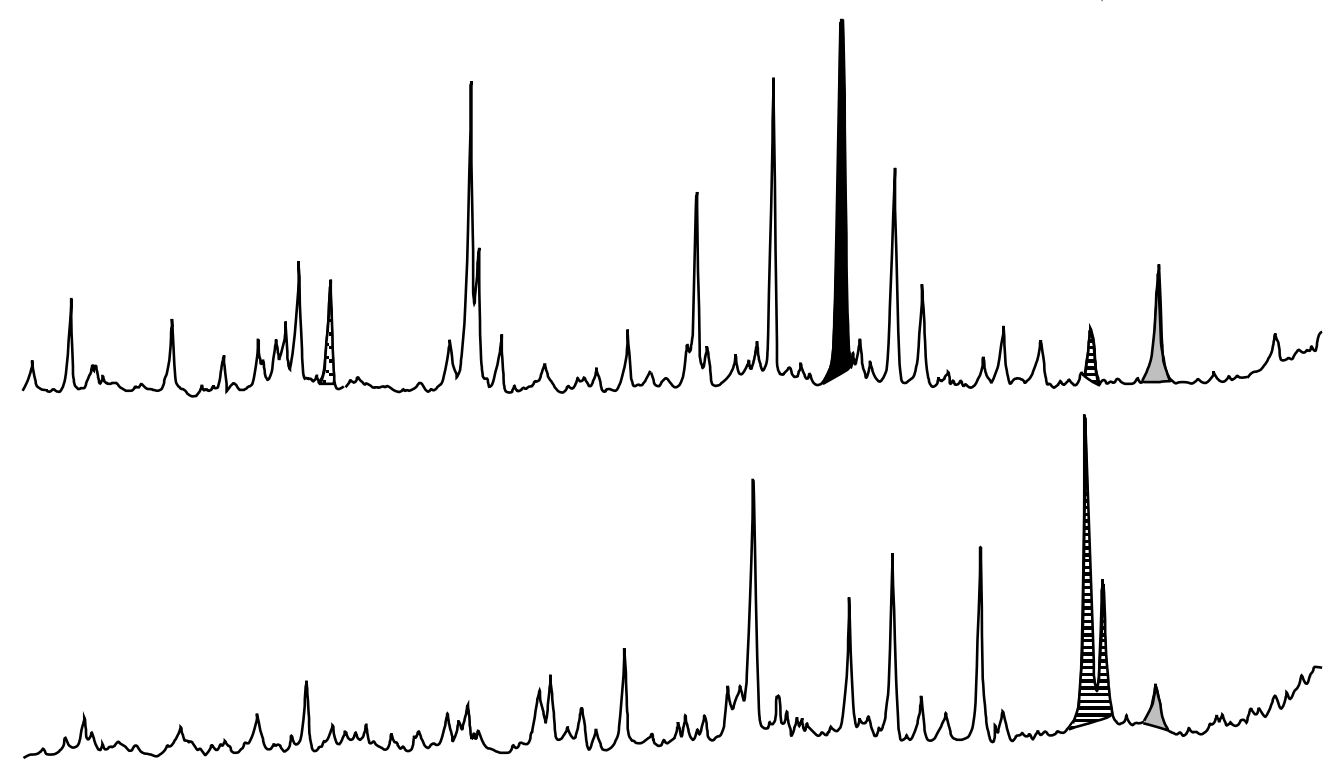

500
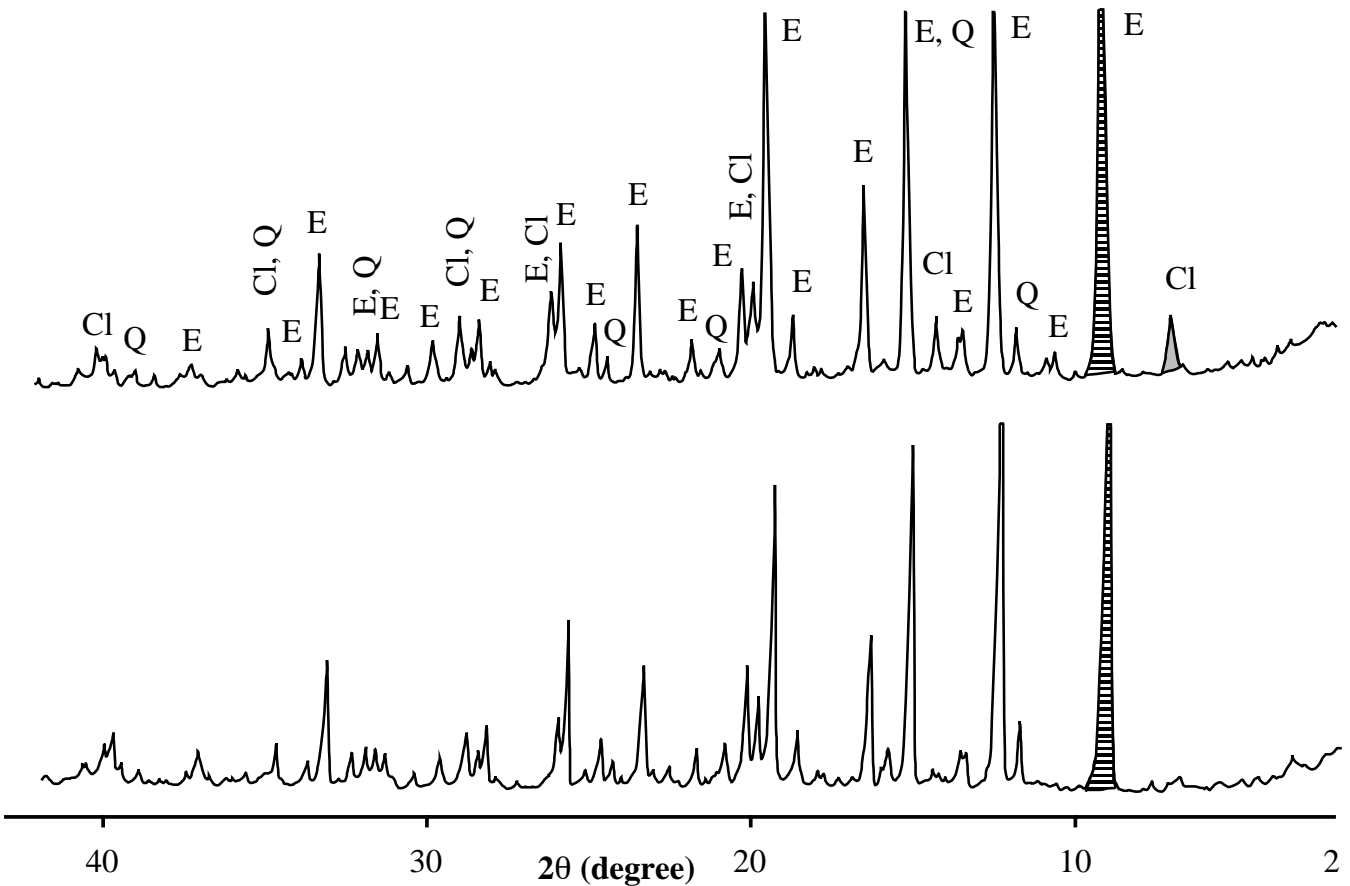

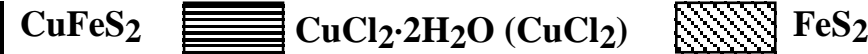

$(\mathrm{Mg}, \mathrm{Fe})_{6}(\mathrm{Si}, \mathrm{Al})_{4} \mathrm{O}_{10}(\mathrm{OH})_{8}$

Fig. 13 : Results of XRD analysis of the LGC chlorination residues obtained at different temperatures. 


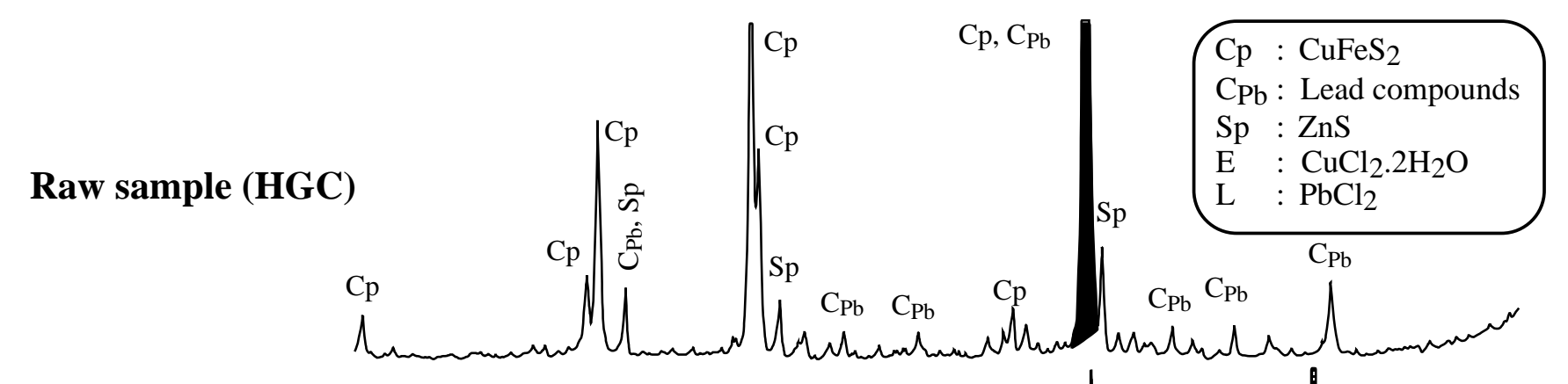

Treated at $\mathbf{T},{ }^{\circ} \mathrm{C}$

150

250

300

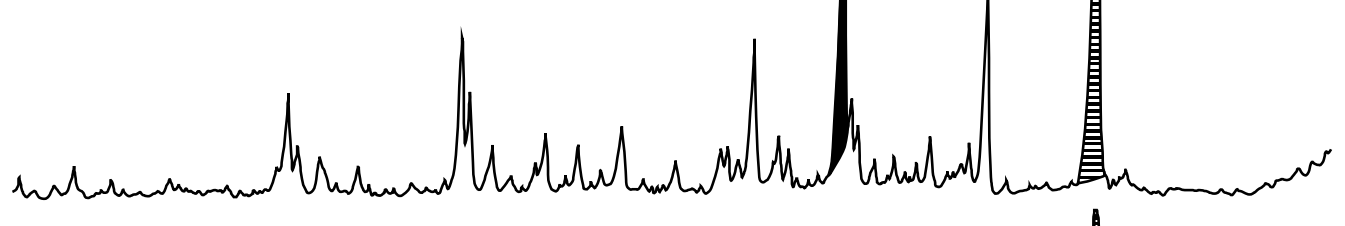

500

700 


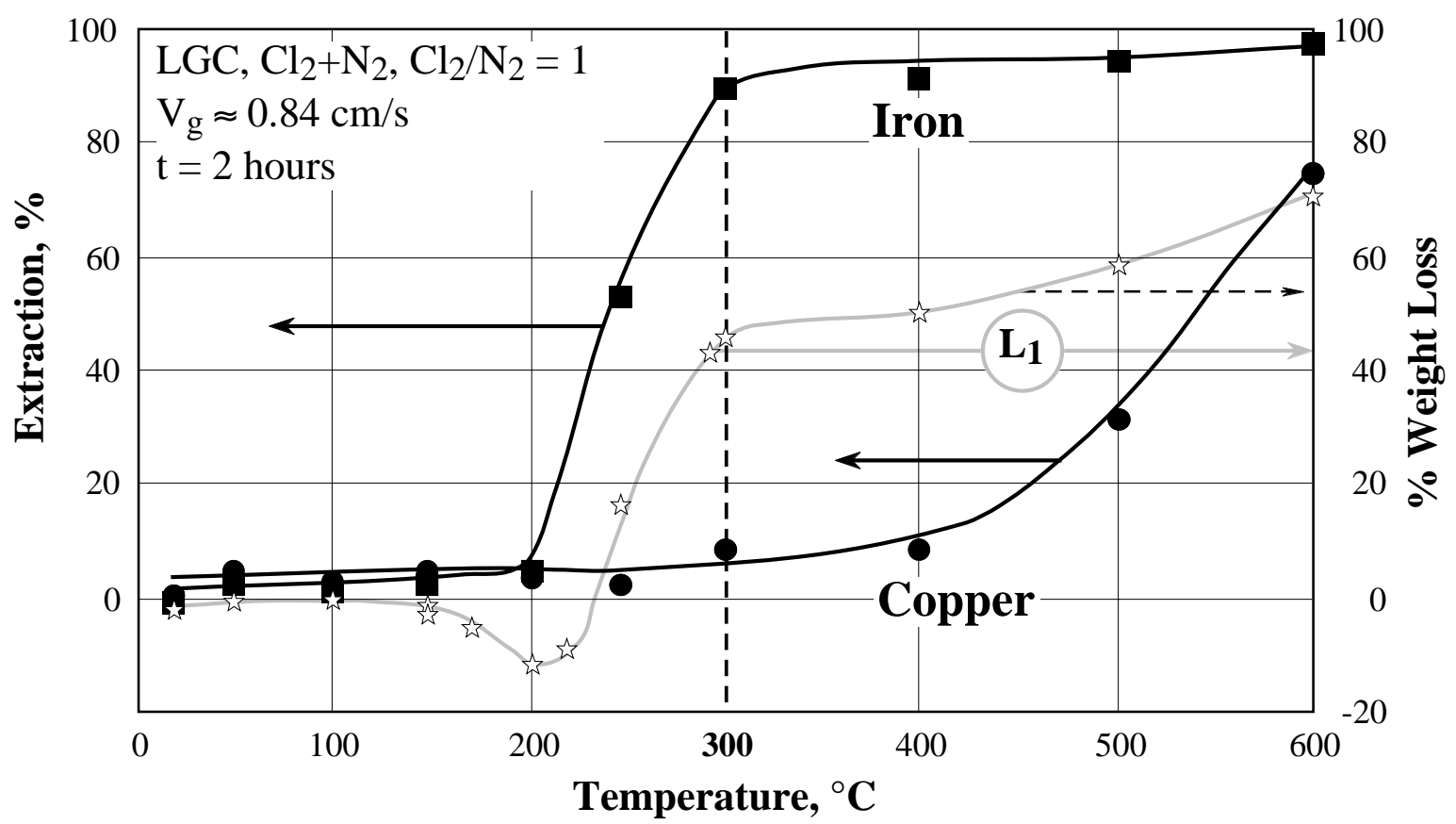

$\mathrm{L}_{1}: \% \mathrm{WL}$ calculated for full chlorination of sulfides and volatilization of Fe and $\mathrm{S}$ chlorinated compounds for LGC.

Fig. 15 : Extraction of copper and iron from LGC during its chlorination at different temperatures.

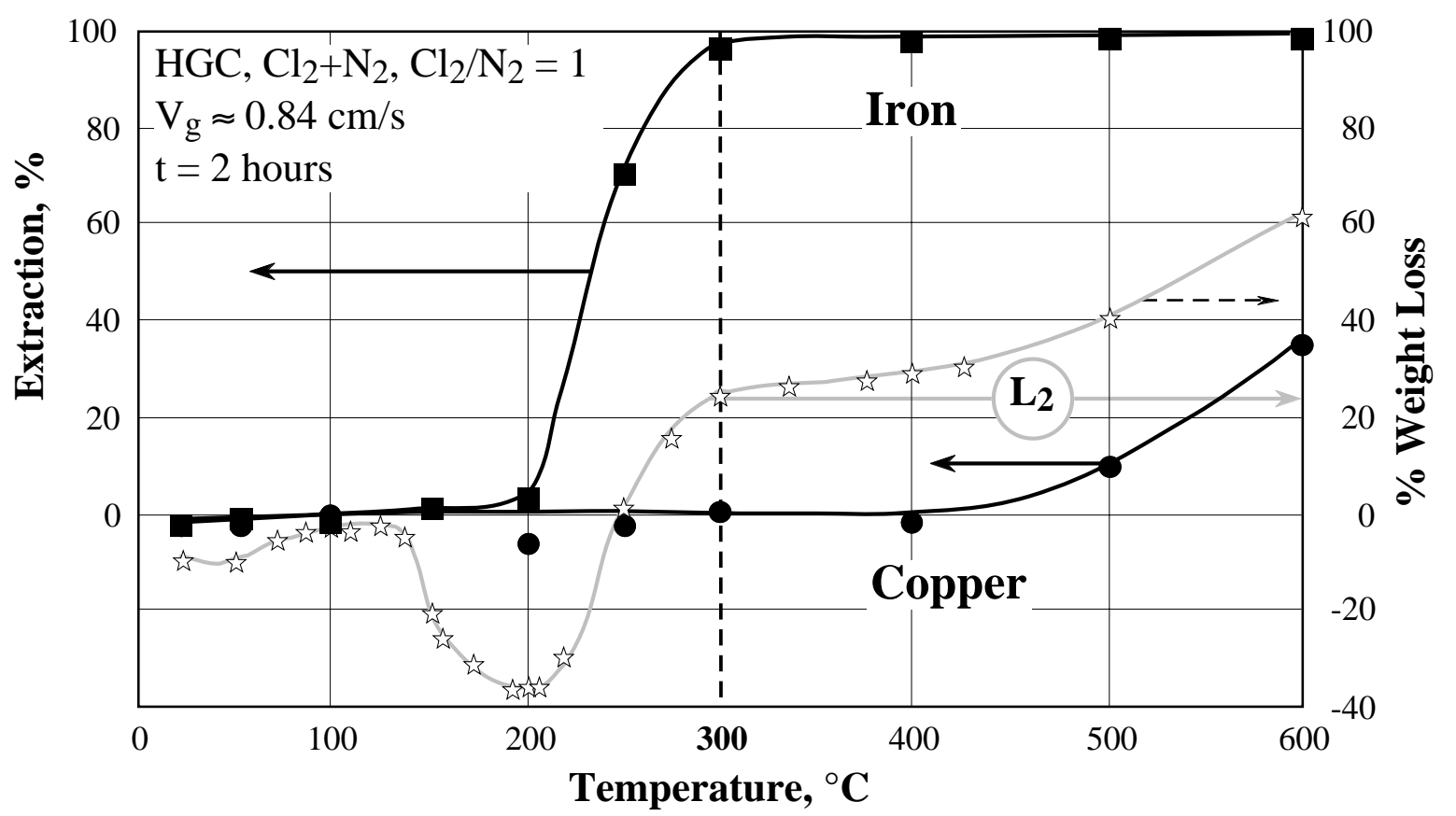

$\mathrm{L}_{2}: \% \mathrm{WL}$ calculated for full chlorination of sulfides and volatilization of $\mathrm{Fe}$ and $\mathrm{S}$ chlorinated compounds for HGC.

Fig. 16 : Extraction of copper and iron from HGC during its chlorination at different temperatures. 

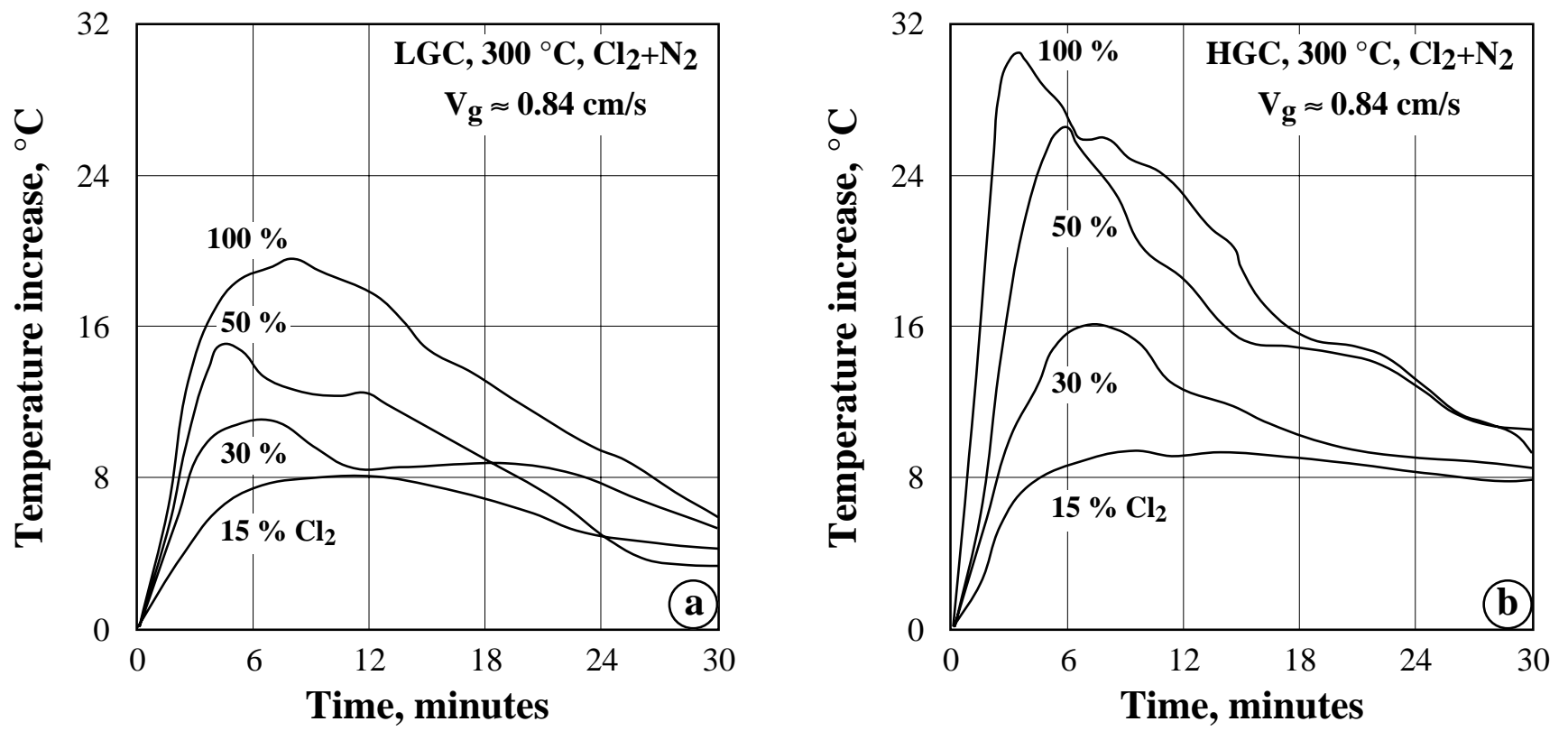

Fig. 17 : Increase of temperature during the chlorination of $(a)$ LGC and $(b)$ HGC at $300{ }^{\circ} \mathrm{C}$ using different chlorine contents in the $\mathrm{Cl}_{2}+\mathrm{N}_{2}$ gas mixture.
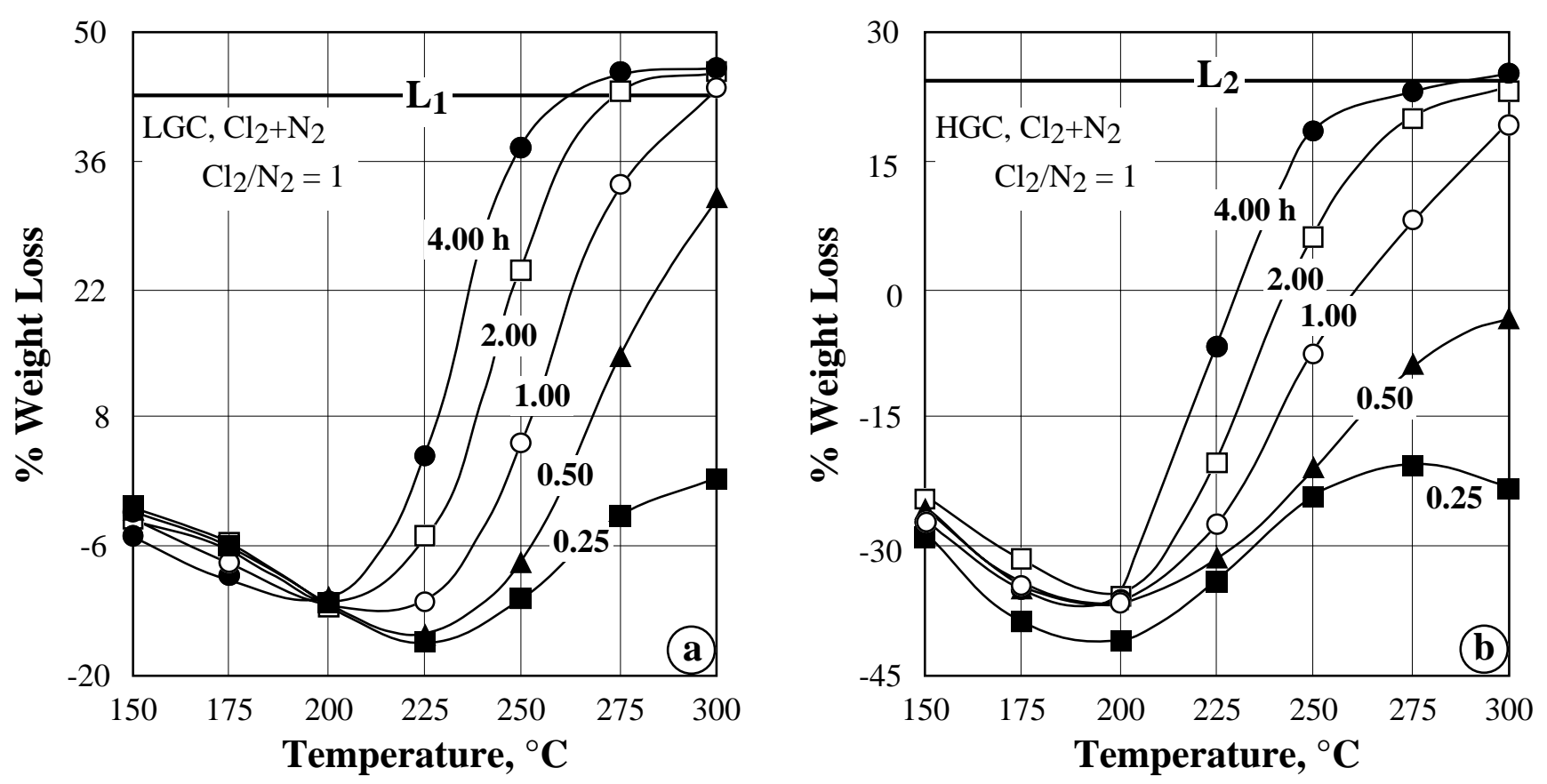

Fig. 18 : Chlorination of (a) LGC and (b) HGC between $150{ }^{\circ} \mathrm{C}$ and $300{ }^{\circ} \mathrm{C}$ for different reaction times. 


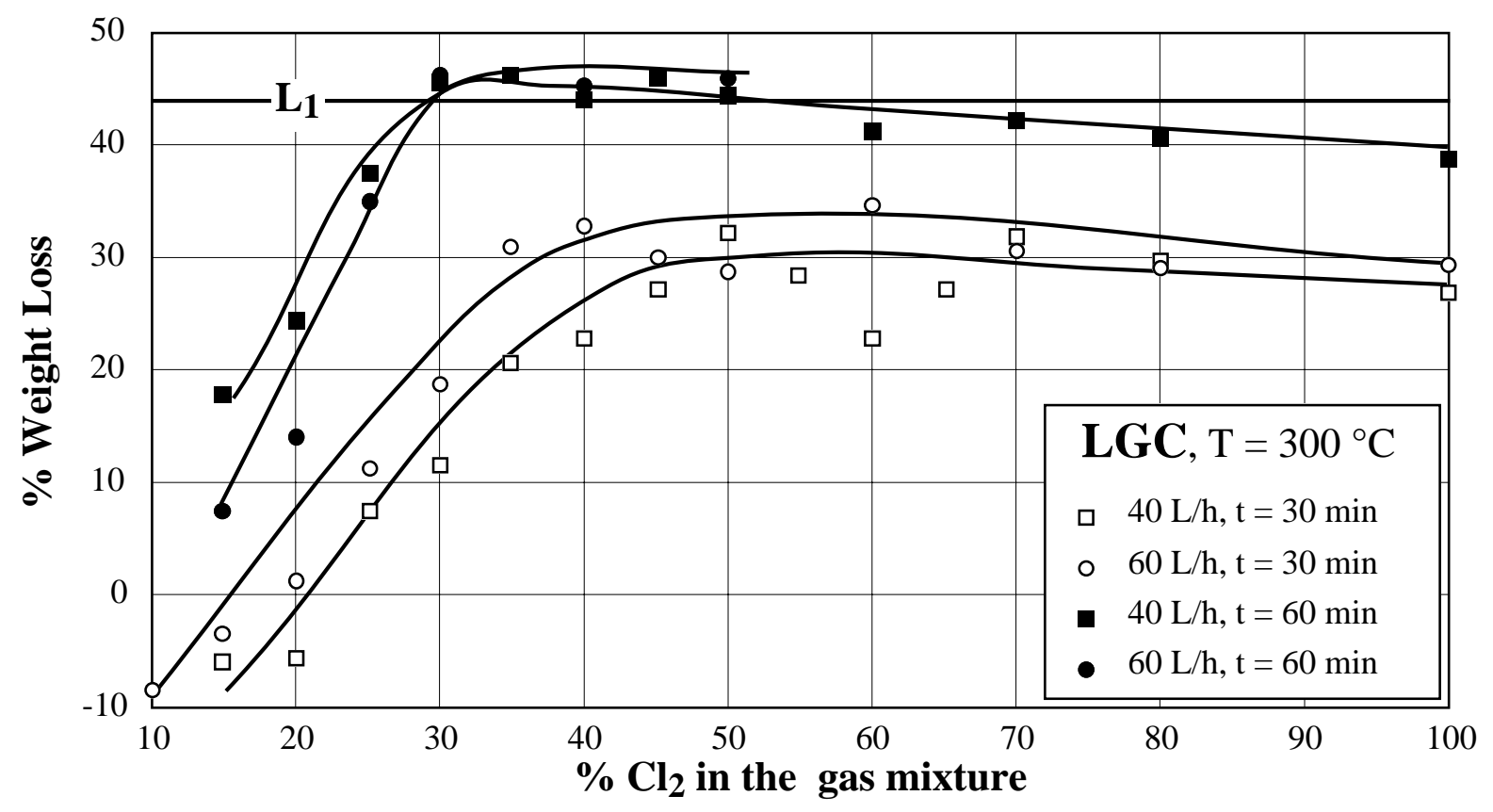

Fig. 19 : Chlorination of $\mathrm{LGC}$ at $300^{\circ} \mathrm{C}$ using various chlorine contents in the gas mixture.

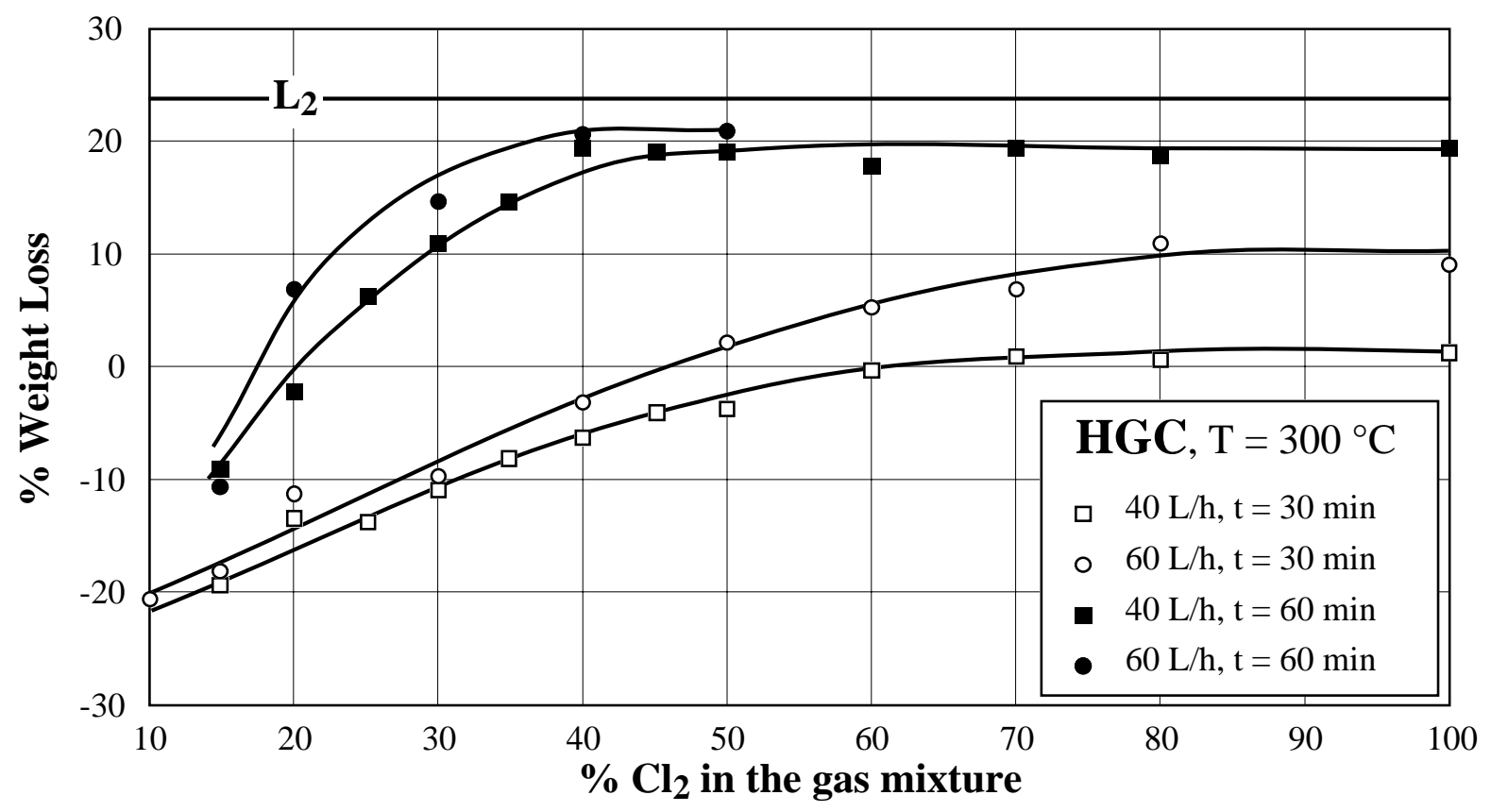

Fig. 20 : Chlorination of $\mathrm{HGC}$ at $300{ }^{\circ} \mathrm{C}$ using various chlorine contents in the gas mixture. 


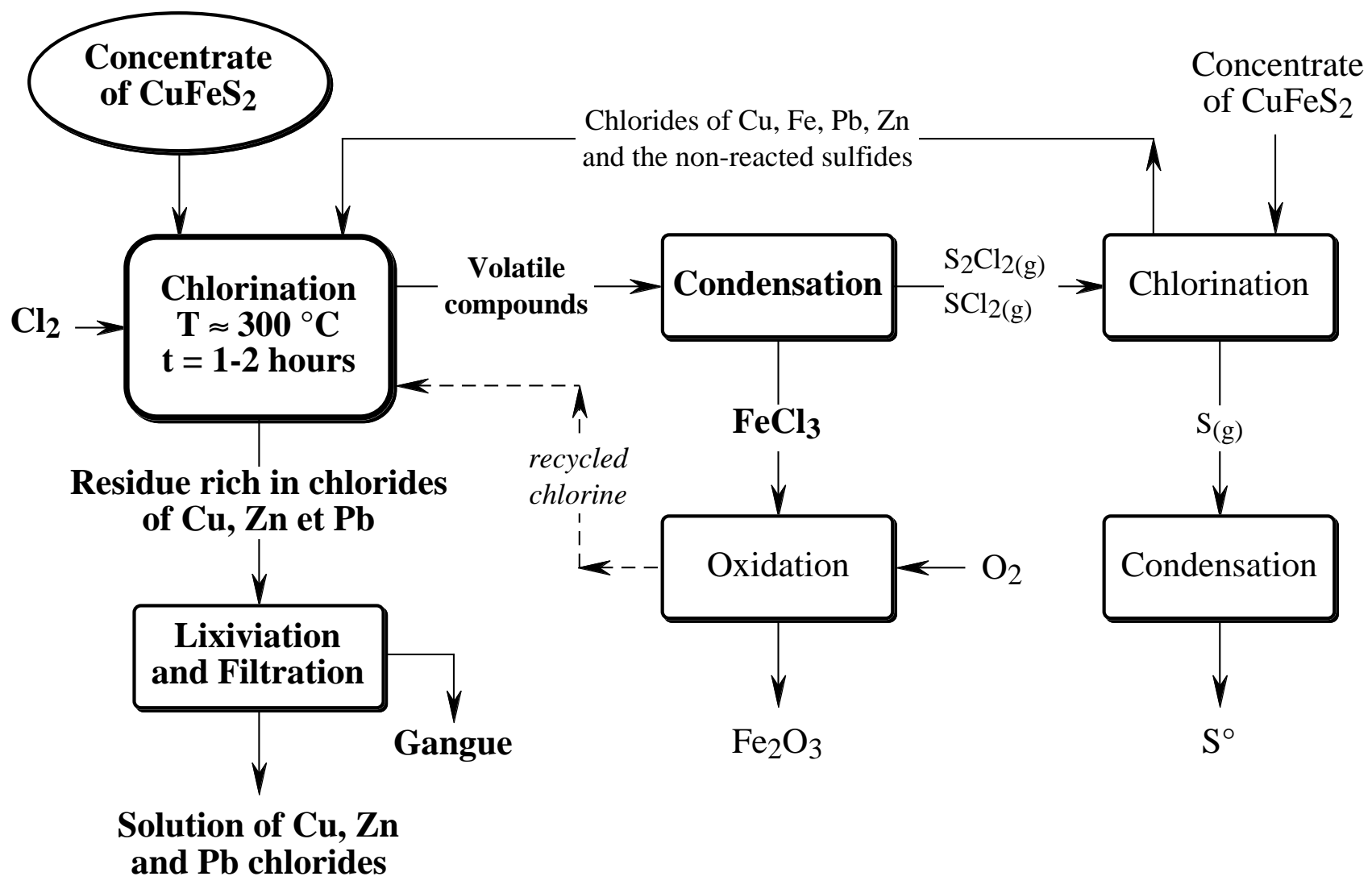

Fig. 21 : Suggested flow-sheet for the extraction of valuable metal chlorides by chlorination of chalcopyrite concentrates at low temperatures. 